\title{
Developing and Validating a Model of Job Enrichment for Academic Staff: A Qualitative Study
}

Roghiyeh Fathi ${ }^{1}$ Ph.D. Student of Higher Education Management, Faculty of Management, Kharazmi University, Tehran, Iran.

Hassanreza Zeinabadi² ${ }^{2}$ Associate Professor, Department of Educational Management, Kharazmi University, Tehran, Iran (Corresponding Aurthor).

Abdolrahim Nave-Ebrahim ${ }^{3}$ Professor, Department of Educational Management, Kharazmi University, Tehran, Iran.

Bizhan Abdollahi ${ }^{4}$ Associate Professor, Department of Educational Management, Kharazmi University, Tehran, Iran.

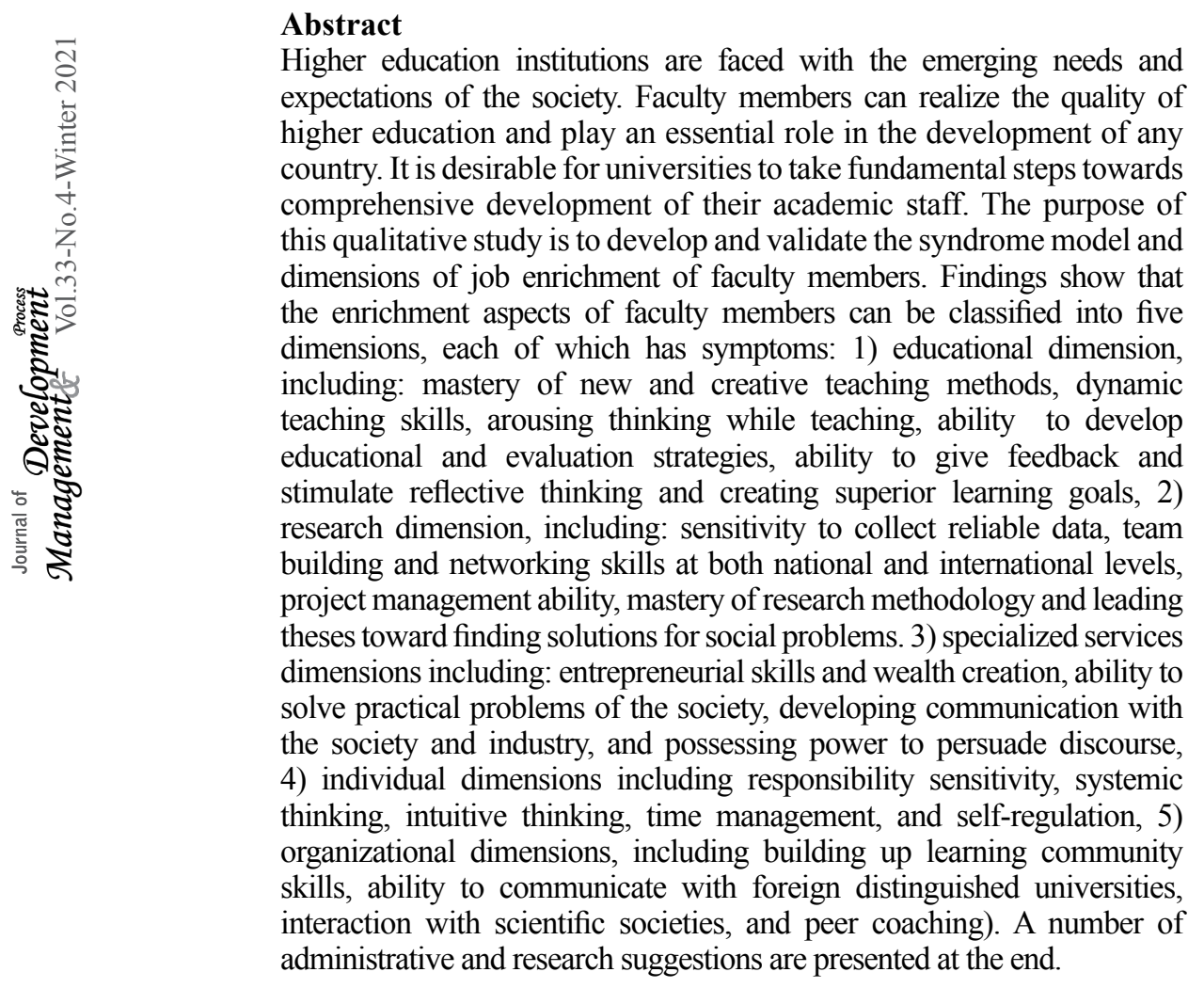

Keywords: Job Enrichment, Syndrome, Dimensions, Faculty Member, Model, Qualitative Study.

\footnotetext{
1. std rfathi94@khu.ac.ir

2. zeinabadi_hr@khu.ac.ir

3. navehebrahim@khu.ac.ir

4. biabdollahi@khu.ac.ir
} 


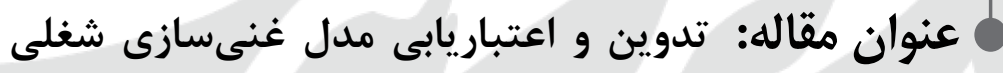
اعضاى هيئت علمى: يافته وناى يكى مطالعه

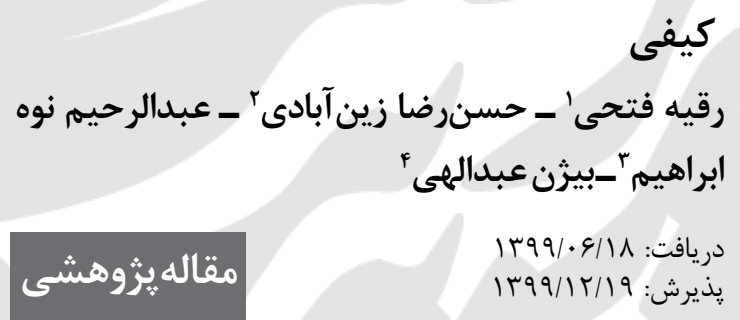

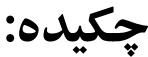

موسسه هاى آموزش عالى با نياز ها و انتظارهاى نويديد جامعه روبلروو هستند. اعضاى هيئت

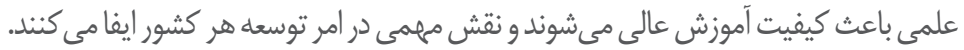

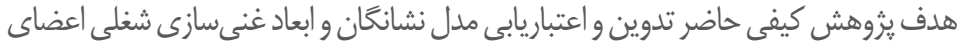

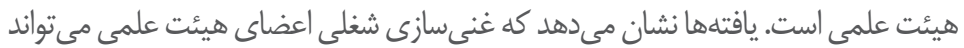

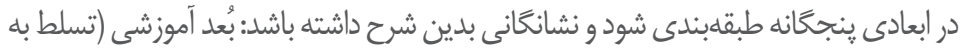

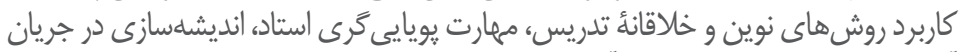

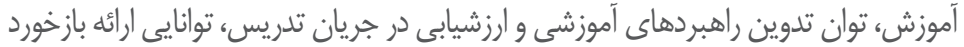

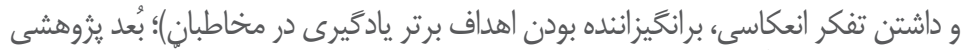

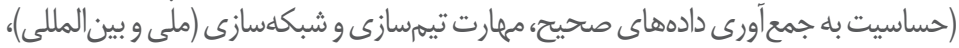

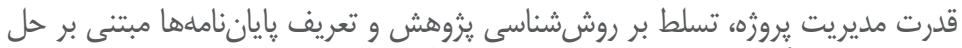

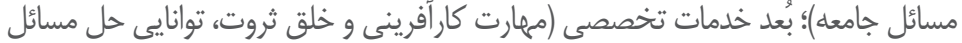

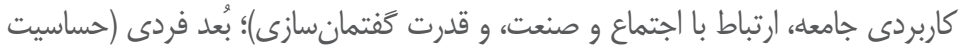

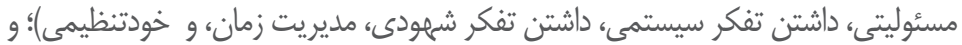

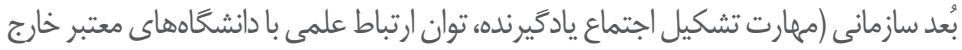

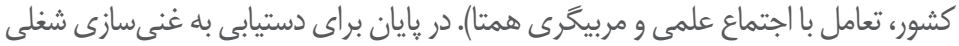

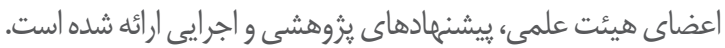

كليدوازهها: غنى سازى شغلى، نشانگًان، ابعاد، هيئت علمى، مدل،

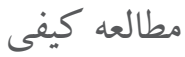

1. دانشجوى دكترى مديريت آموزش عالى، دانشكده مديريت، دانشكاه خوارزمى تهران، ايران. std_rfathi94@khu.ac.ir

$$
\text { r. دانشيار گروه مديريت آموزشى، دانشگاه خوارزمى، تهران، ايران (نويسنده مسئول). }
$$

zeinabadi_hr@khu.ac.ir

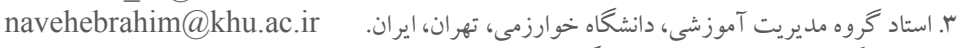

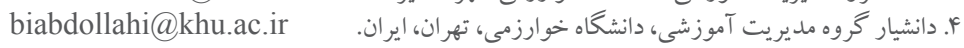




\section{مقدمه}

يزوهشهاى علمى در فرايند رونق اقتصادى نقش كليدى دارند و در كشورهاى توسعهيافته همواره به دانشخاه به عنوان مركز يثوهش توجه مىشود. امروزه، در كشورهاى درحالتوسعه نيز تلاش مى شود بين آموزش عالى و برنامههاى توسعه ملّى و ارتقاى دانش و فناورى ارته ارتباط برقرار

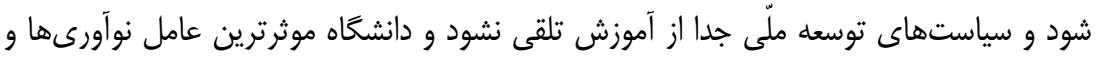

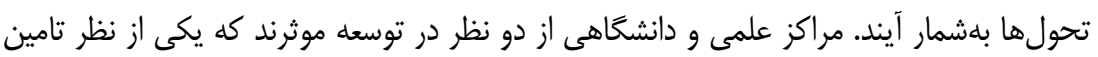
نيروى انسانى با كارايى بالا و ديخرى از نظر گسترش مرزهاى علم و دانش و ييشبرد فناورى است.

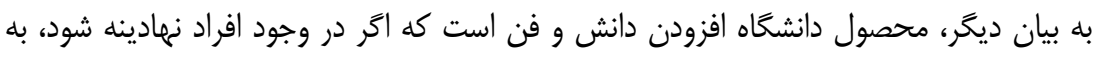
عنوان كارايى نيروى انسانى تلقى مىشود و اگر جدا از وجود انسان باشد، به صورت مجموعه دانش و فناورى نمايان مىشود (حيدرى و رضايى، عهسا).

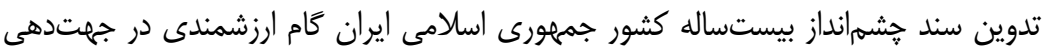
فعاليتهاى كشور براى رسيدن به توسعه است و از مهمترين فرازهاى سند، توجه ويزه به جايكاه

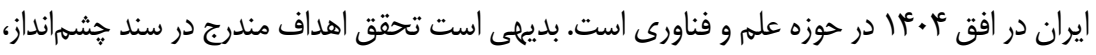
مديريت و تدبير جامع در تمامى ابعاد را مىطلبد و لازم است در حوزه مديريتى علم و فناورى،

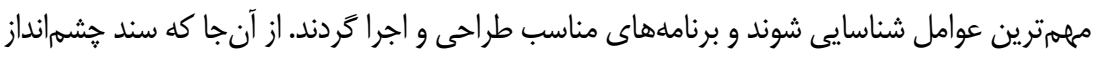

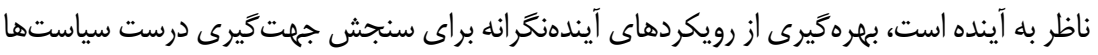

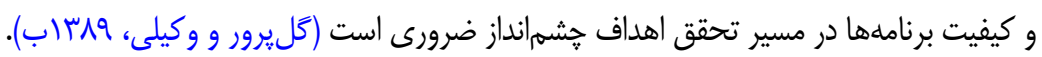
कर

4

3 يكى از حوزههاى داراى اهميت در توسعه علم و فناورى توجه ويثه به آينده تحولهاى شغلى اعضاى هيئت علمى به عنوان سرمايههاى فكرى دانشخاهى و برنامهريزى مستمر براى ايران

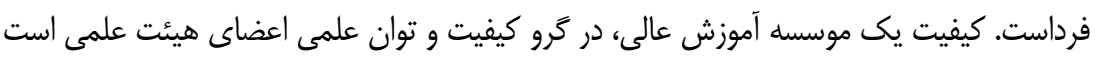
و يك موسسه آموزش عالى بدون برخوردارى از اعضاى هيئت علمى مجرزز به علم و دانش، توان و

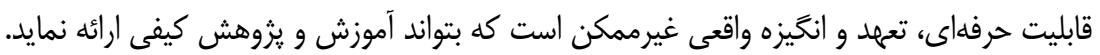

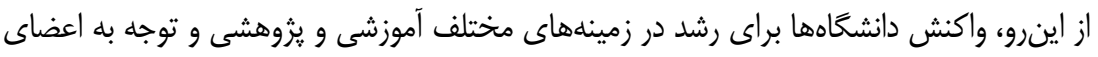

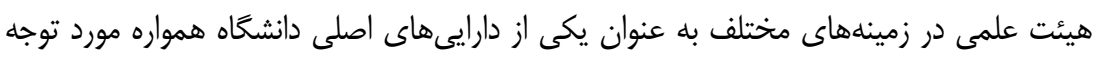

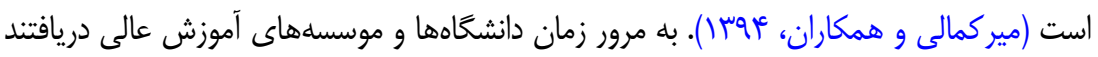


كه نيازمند برنامههايى هستند كه بلهور اساسى در مديريت، توسعه و بهسازى اين سرمايه به آنها

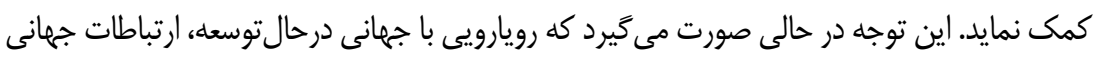

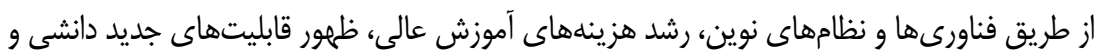

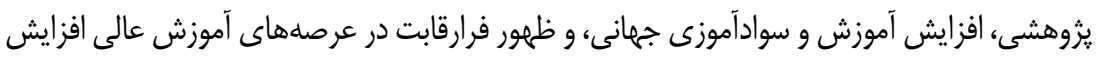

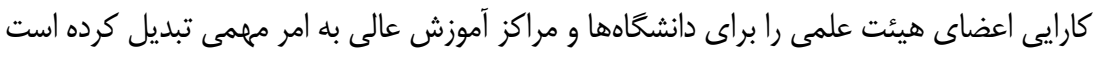
(Barnett, 2001). دانشخاهها و مراكز آموزش عالى توسط نيروهاى قدرتمندى احاطه شدهاند كه

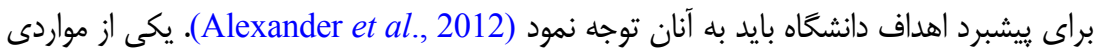

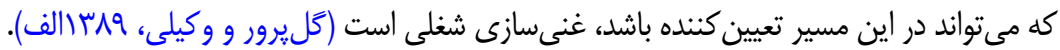
افزايش دانش، تخصص، و مهارت در اعضاى هيئت علمى دانشكاه همواره از دغدغههاى

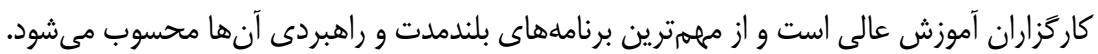

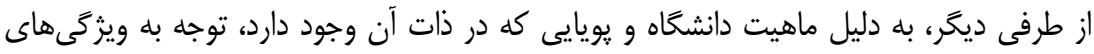

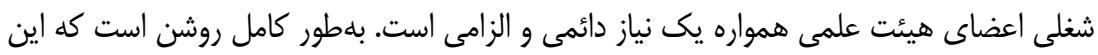

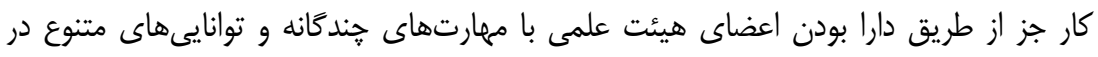

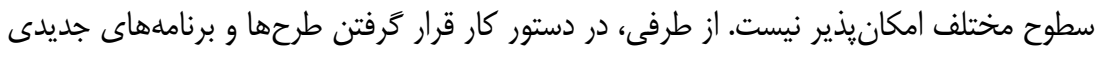

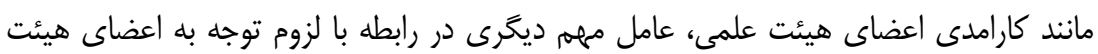

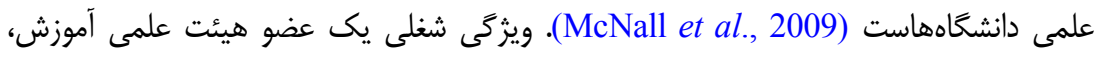

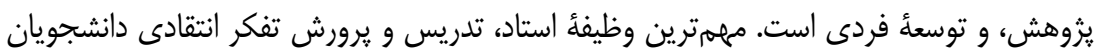

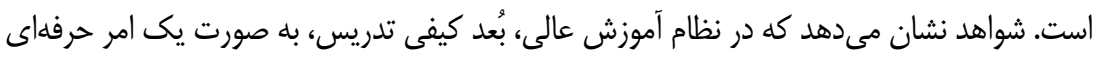

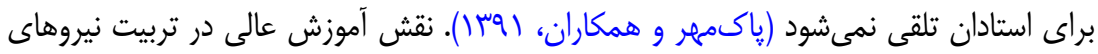

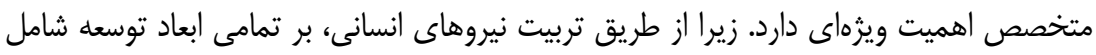

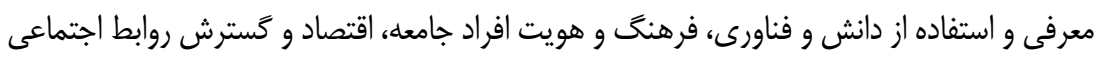

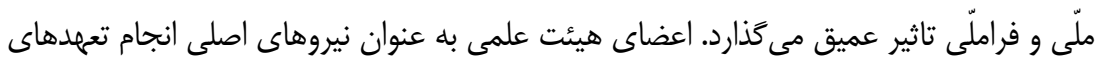

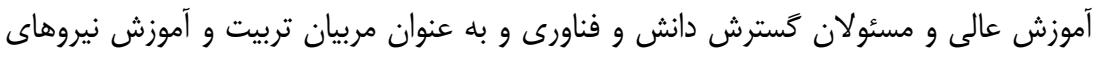

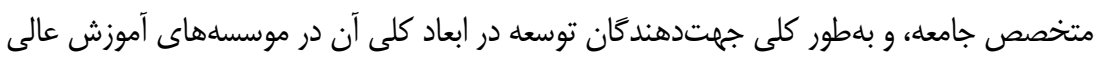

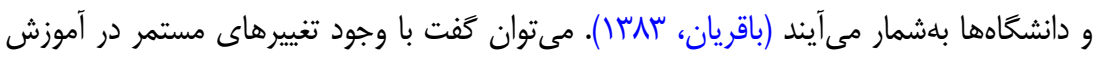

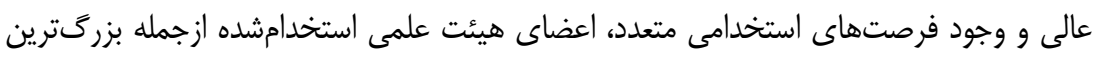
منابع موجود در دانشخاهها و دانشكدها هستند (Alstete, 2000). باور بر اين است كه ميزان و كيفيت انجام نقشها و وظايف اعضاى هيئت علمى وابسته دهائه 
به ميزان انكيزش و باور درونى به انجام شغلى است كه اين افراد در حال انجام آن هستند

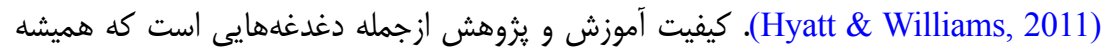

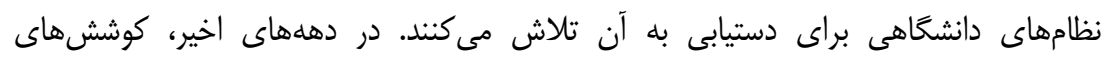

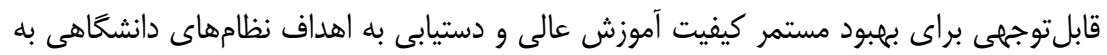

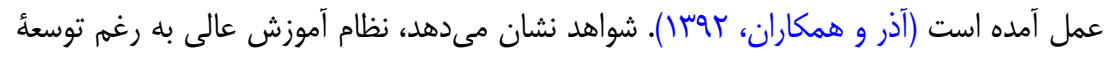
كمّى جندساله اخير نتوانست مهمترين رسالت خود را كه تربيت نيروى انسانى متخصص، ارتقاى

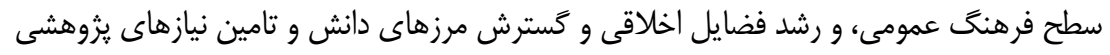

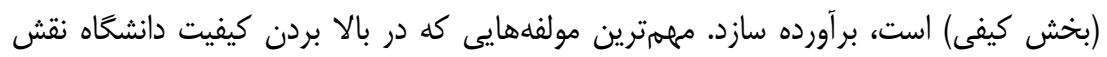

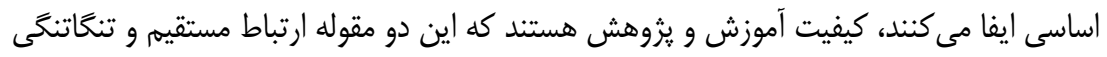
با كيفيت اعضاى هيئت علمى دارند. رشد كيفيت اعضاى هيئت علمى باعث افزايش كيفيت آموزش و يزوهش مىشود (آذر و همكاران، بهوسا).

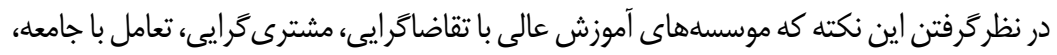

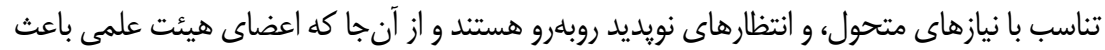

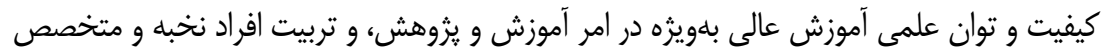

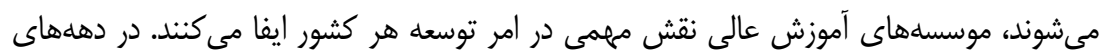
اخير، به دليل تغيير در تنوع دانشجويان، فناورىها، انتظارها و نيازهاى دانشى در هر رشته و رقابت هرايت

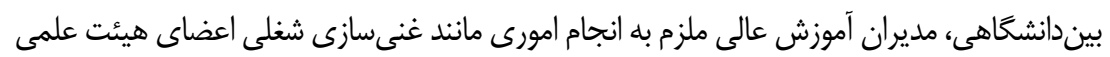
شدهاند (Gappa, 2008). بر اساس اين، توجه به غنى سازى شغلى استادان كه هدف آن انجام بهتر

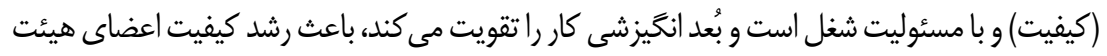
علمى مىشود. بررسى نتايج يزوهشهاى انجامشده در حوزه غنىسازى شغلى اعضاى هيئت علمى

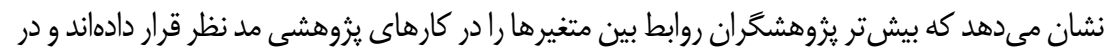
عمل يزوهشى در حوزه تدوين مدل غنى سازى شغلى اعضاى هيئت علمى در دانشخاههاى كشور انجام

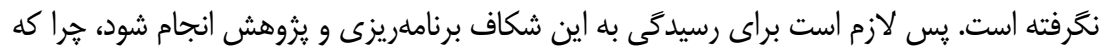

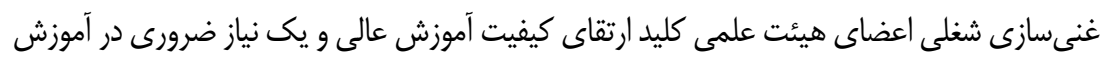

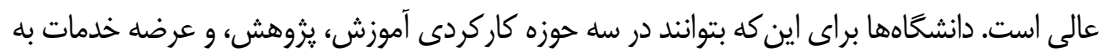

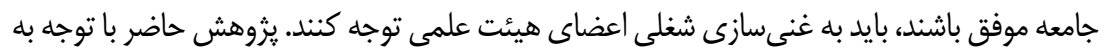

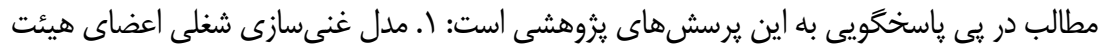

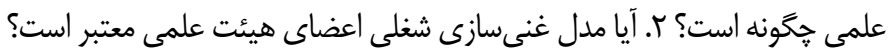




\section{مبانى نظرى يزوهش}

غنىسازى شغل يعنى برانكَيزندهاى بيشترى به كار افزوده مىشود تا آن شغل را دلحسبتر و سودبخشتر سازد؛ اگر خه اين عبارت هماكنون هر كوششى را كه براى درخور انسان كردن كار

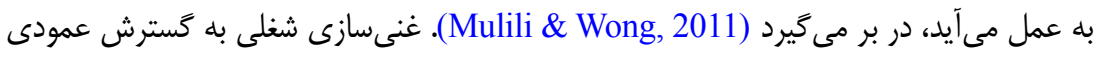

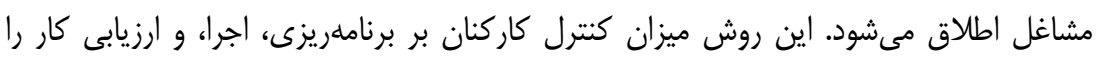

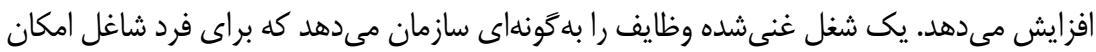

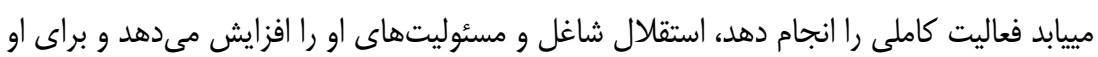

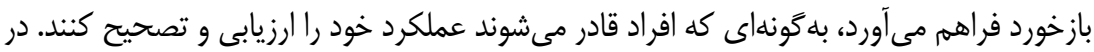

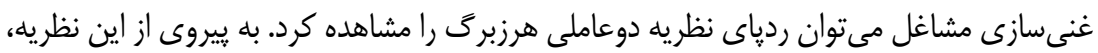
با افزايش عوامل درونى در يك شغل (نظير موفقيت، مسئوليت، و رشد) كاركنان بيشتر الترات إتمال

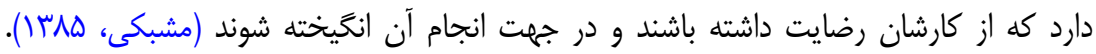

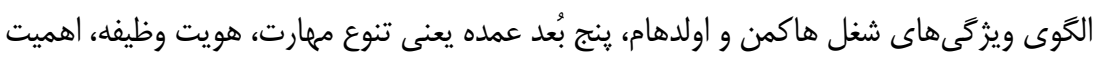

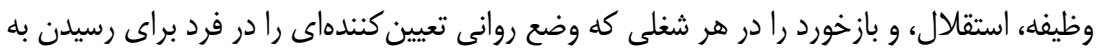

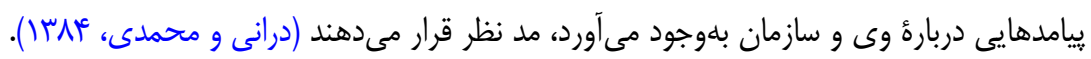
ابعاد غنىسازى شغلى از ديدگًاه رابينز 'عبارتاند ازئ

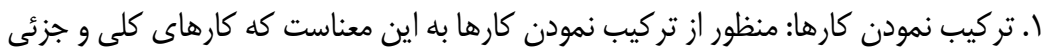

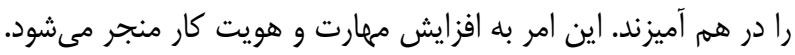

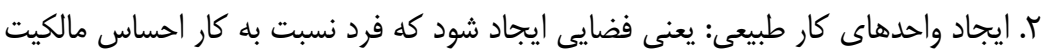
داشته باشد، نه اين كه دركير فعاليتهاى قالبى باشد. س. ايجاد رابطه با مشترى: بدين معناست كه فضايى ايجاد شود كه فرد بتواند با مشتر يان بلهور

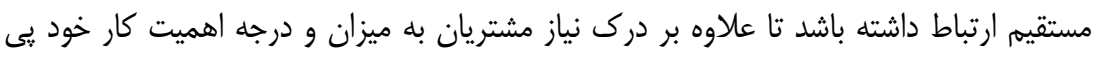
ببرد. א. بسط يا كسترش شغل در سطح عمودى: به اين معنا كه به فرد آزادى عمل و خودمختارى داده شود. به عبارت ديخر، تفويض اختيار به نيروى كار.

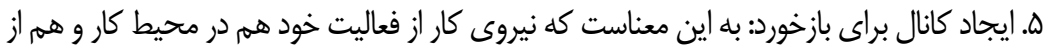
ديد مشترى بازخورد بخيرد تابه دركى از نتيجه فعاليتهاى خود برسد (Oldham \& Hackman 2010). 
همجنين هرزبرك' عقيده دارد كه مىتوان از راه تجربه هاى مثبت مرتبط با كار، مانند احساس

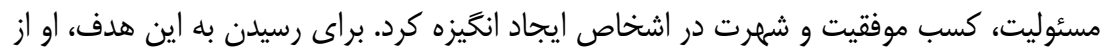

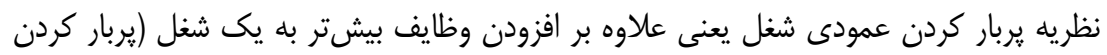

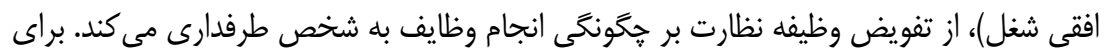

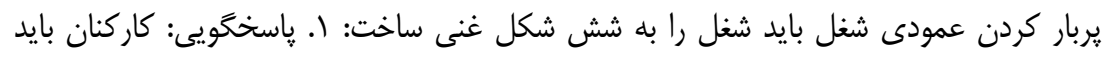

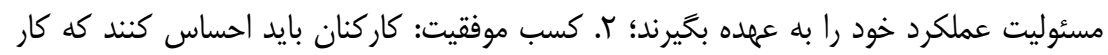

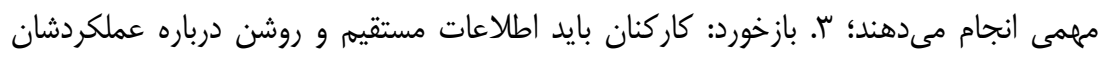

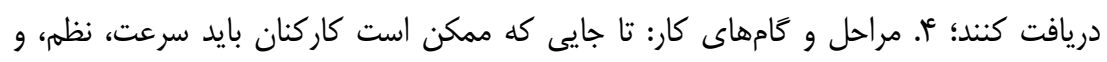

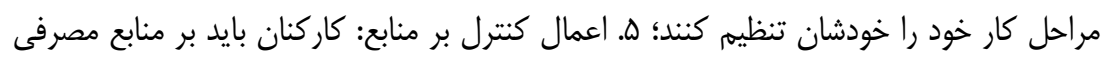

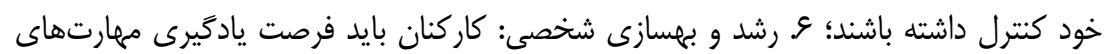
جديد را داشته باشند (مورهد و كريفين، عرسا).

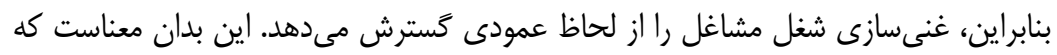

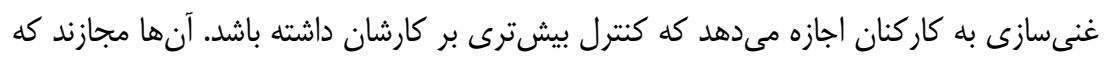

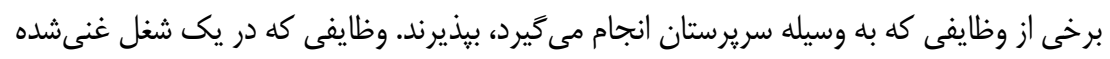

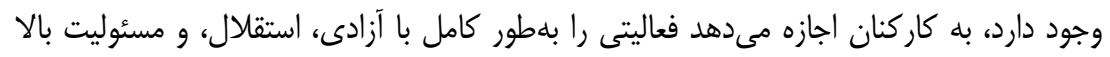

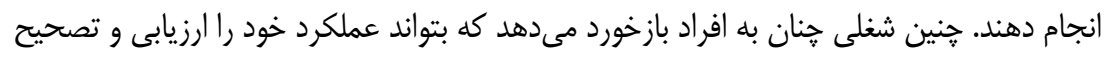

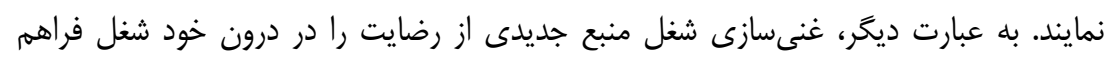

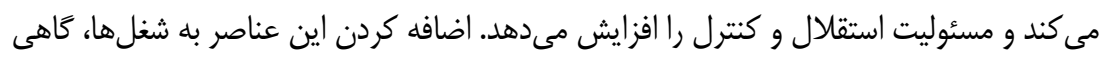

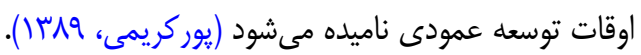

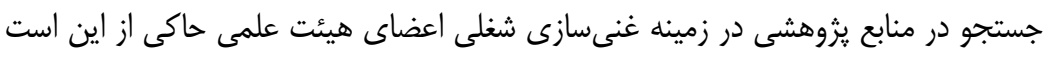

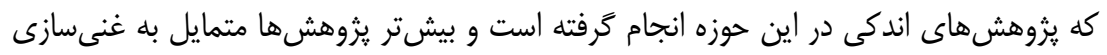

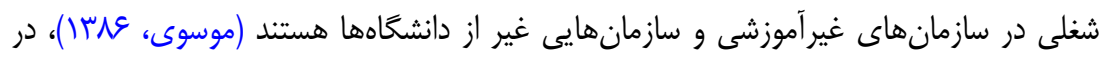

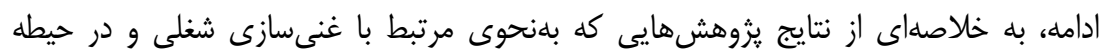

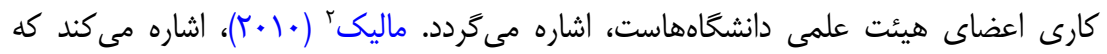

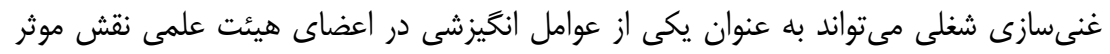

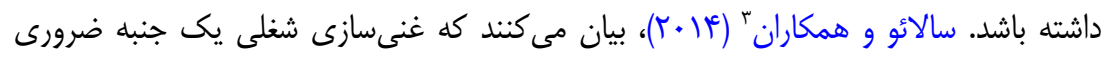

1. Herzberg

2. Malik

3. Salau et al. 
در انخيزش كاركنان براى عملكرد بهتر و بيشتر از طريق يك حس مشترك براى نوع مهارت،

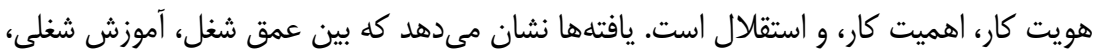
و عناصر بُعد شغلى غنىسازى شغلى و عملكرد كاركنان رابطه مثبت وجود دارد، در حالى كه

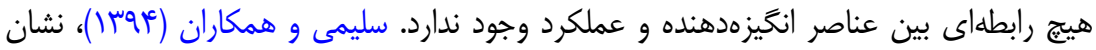

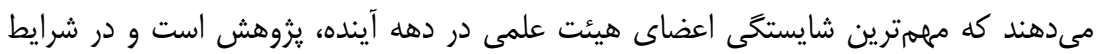
موجود شايستىى تدريس اعضاى هيئت علمى وضع مطلوبترى دارد. قنبرى و همكاران (أوسا)، مولفههاى اخلاق حرفهاى را در جهار دسته توانمندى حرفهاى، احترام و تعهد به دانشجويان، احترام و تعهد به همكاران، و احترام و تعهد به سازمان تقسيم مى كنند. در يزوهش عبدالمهى و حيدرى

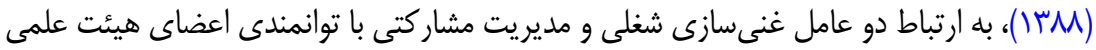

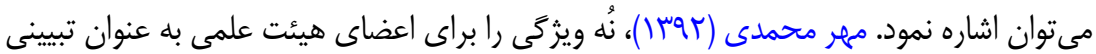
از تدريس مطلوب برمىشمارد كه شامل مادامالعمر يادگيرنده بودن، اقتدار و تسلط علمى، يإيبندى إنى به اخلاق حرفهاى، نظم و انضباط در رفتار و سلوك حرفهاى، احساس همدلانه با دانشجو، تالاش در جهت يادكيرى دانشجويان، و لذتبخش ساختن تدريس در عين جدى بودن محيط كلاس

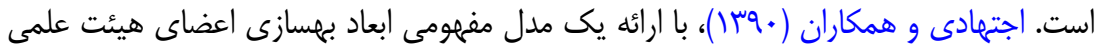

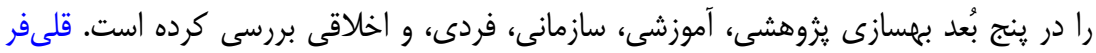

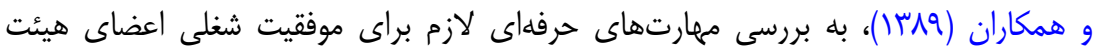

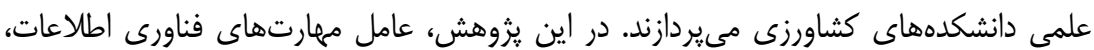
مهارتهاى ارتباطى، تسلط بر محتوا، راهبردهاى تدريس و يادگيرى، و بالندگى حرفهاى به عنوان

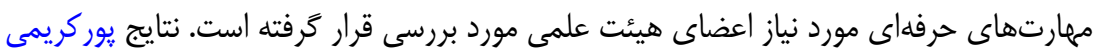

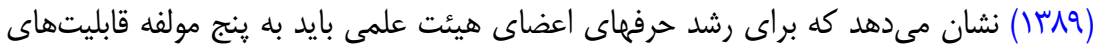

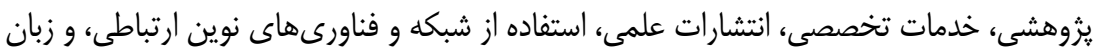
انكَليسى توجه كرد. الكياوى و عزالدين' (ها • ())، به بررسى قابليتهاى اعضاى هيئت علمى مىيردازند. آنها اين

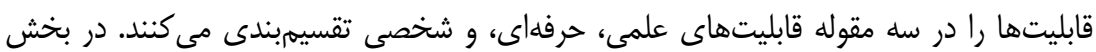

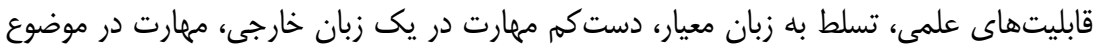

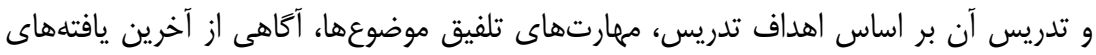

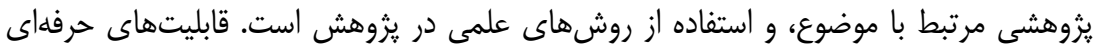

1. Alqiawi \& Ezzeldin 
شامل طراحى درس بر طبق روشهاى تدريس مناسب، ارائه درس و مديريت كلاس، استفاده از

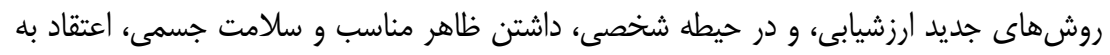

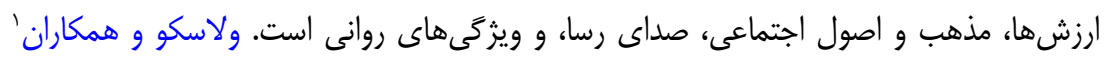

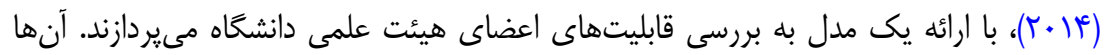

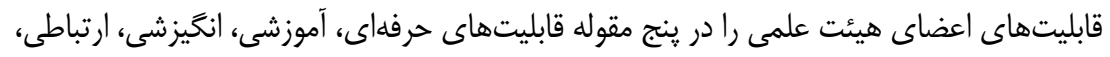

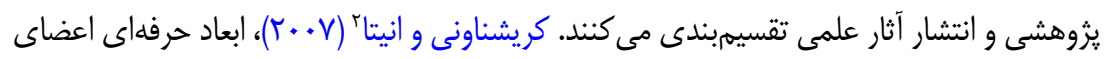

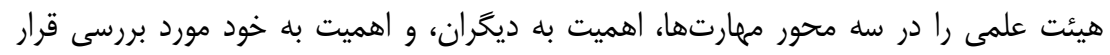

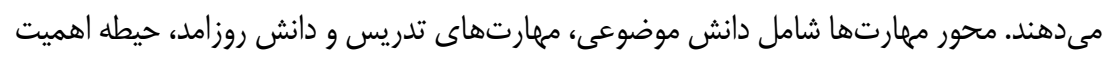

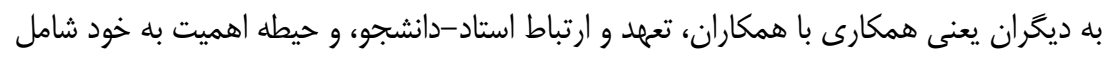

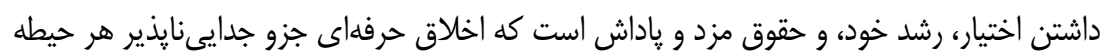

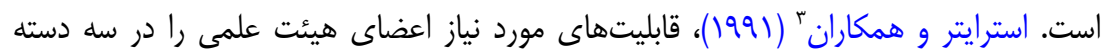

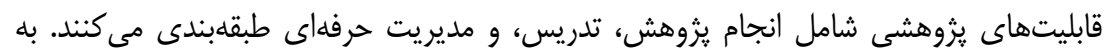
اعتقاد آنان، براى ايفاى بهتر وظايف و نقش هايى كه اعضاى هيئت علمى بر عهده دارند، بايد مجهز

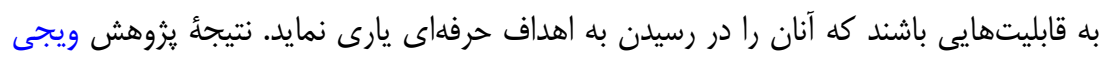

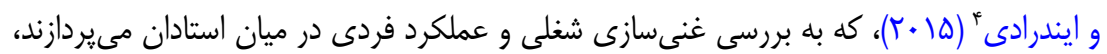

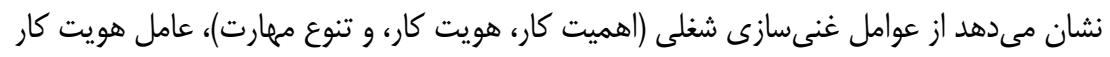
بر افزايش عملكرد افراد نقش بيشترى دارد.

\section{روش}

يزوهش حاضر يك يزوهش كاربردى است كه به روش كيفى انجام شده است. پِ از بر برسى

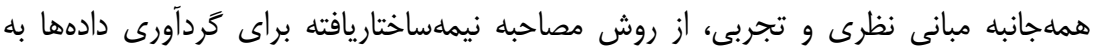

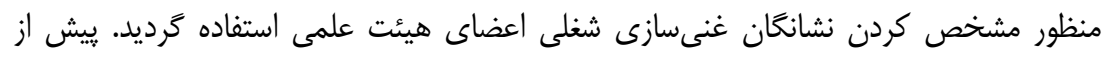

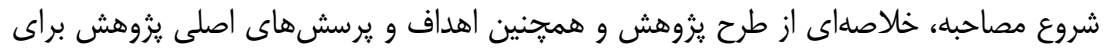

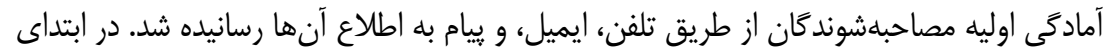

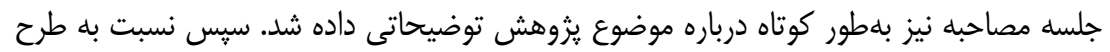

1. Velasco et al.

2. Krishnaveni \& Anitha

3. Stritter et al.

4. Vijay \& Indradevi 
يرسشهاى مصاحبه و انجام فرايند مصاحبه اقدام شد. به منظور ثبت دادهاى كيفى و تمركز بيشتر مصاحبه كننده بر فرايند مصاحبه، تمام مصاحبهها ضبط شده و از نكات كليدى هر مصاحبه يادداشتبردارى صورت كرفته است. همجنين، با وجود اين كه اشباع نظرى در اطلاعرسان هارها

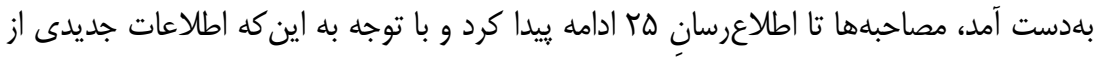

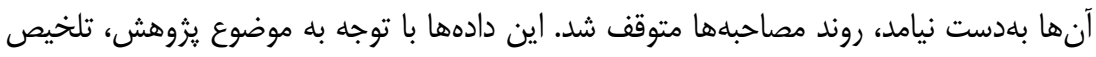

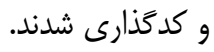

براى تحليل دادههاى كيفى از فرايند كدكذارى باز، محورى، و انتخابى استفاده شد. به منظور

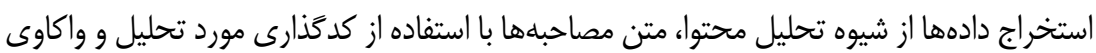

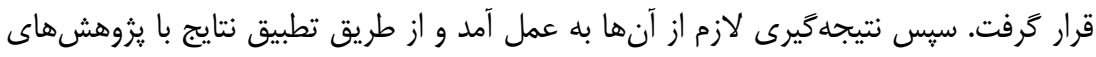

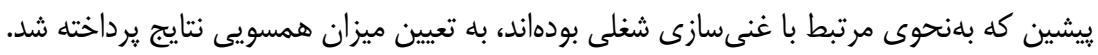

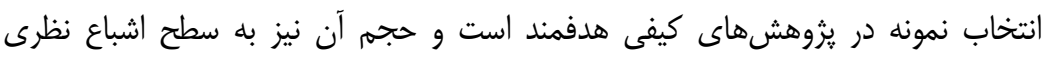

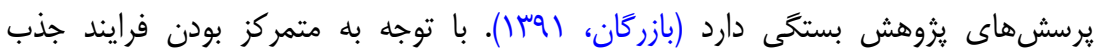

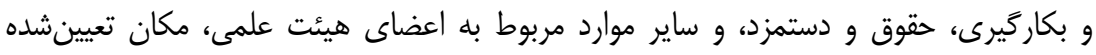

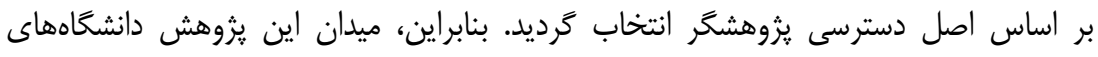

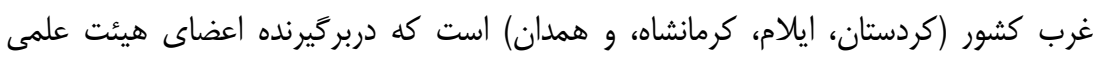

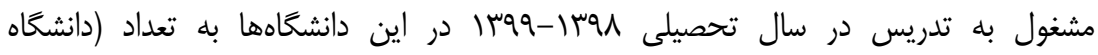

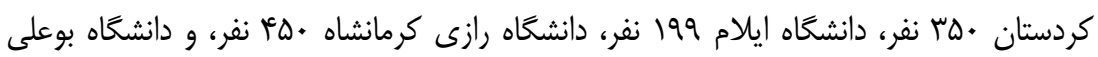

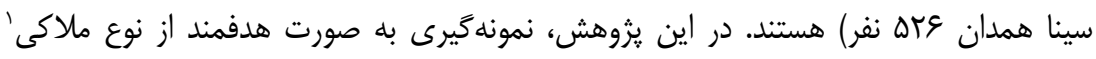

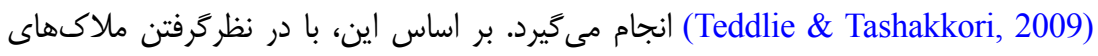

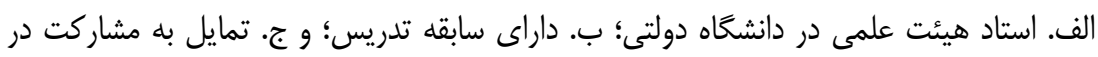

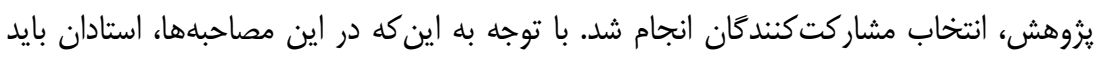

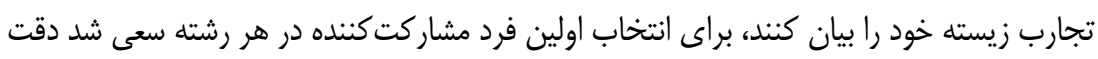

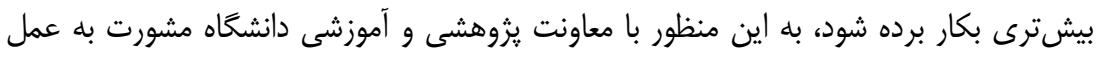

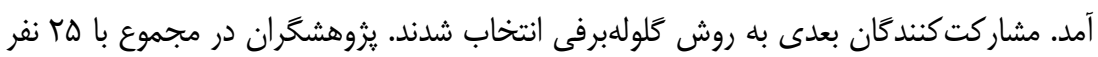

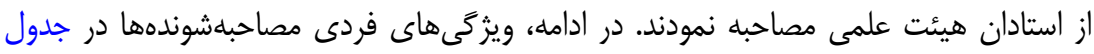

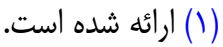

1. Criterion Sampling 
جدول ا: ويزگى هاى فردى استادان عضو هيئت علمى مشار كت كننده در مصاحبه

\begin{tabular}{|c|c|c|c|c|c|c|c|c|c|}
\hline زمان مصاحبه & كد & رشته تحصيلى & $\begin{array}{l}\text { سابقه كار (سال) } \\
\text { (سار }\end{array}$ & شماره & زمان مصاحبه & كد & رشته تحصيلى & سابقه كار & شماره \\
\hline$r$. & 14 & كشاورزى & 10 & 14 & $r$. & .1 & مديريت & 19 & 1 \\
\hline TQ & 10 & برق & v & 10 & Yo & $\cdot t$ & مديريت & 1. & r \\
\hline r. & 19 & تاريخ & v & 19 & ro & r & مديريت & $\wedge$ & r \\
\hline ro & IV & مكانيك & $r$ & IV & $Y Q$ & $\cdot r$ & مديريت & 1. & $r$ \\
\hline ro & 11 & رياضى & 1. & 11 & Q. & $\cdot 0$ & مديريت & 11 & 0 \\
\hline$r$. & 19 & رياضى & 14 & 19 & 4. & .9 & مديريت & ir & 9 \\
\hline Q. & $r \cdot$ & رياضى & 1. & $r$. & r. & $\cdot v$ & مديريت & 9 & v \\
\hline$r$. & YI & ادبيات & 0 & rI & Q. & $\cdot \wedge$ & فناورى آموزشى & 19 & $\wedge$ \\
\hline ro & YT & شيمى & 10 & rT & $r$. & .9 & فيزيك & 4 & 9 \\
\hline$\mu$. & 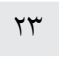 & شيمى & v & r & rQ & 1. & فيزيك & 10 & 1. \\
\hline 0. & YY & شيمى & 1. & TY & $r \cdot$ & 11 & جغر افياى شهرى & v & 1 \\
\hline \multirow[t]{2}{*}{ TQ } & ro & جامعهشناسى & 0 & rQ & $r$. & ir & كامييوتر & 0 & IT \\
\hline & & & & & $r$. & $1 r$ & كامييوتر & 10 & ir \\
\hline
\end{tabular}

همان طور كه در جدول ( () مشاهده مىشود، سابقه كارى مشاركت كنندًان در يزوهش بين ستا 1 ا سال است. در اين يزوهش، اعضاى هيئت علمى رشتههاى مديريت آموزشى، مديريت بازركانى، مديريت منابع انسانى، فناورى آموزشى، فيزيك، جغرافياى شهرى، كامِيوتر، كشاورزى، برق، مكانيك، رياضى، ادبيات، شيمى، و جامعلشناسى مشاركت دارند. در رشته مديريت در گر ايشهايع، إنى منابع انسانى، بازركانى، ورزشى، و آموزشى با هفت نفر، رشته فناورى آموزشى يكى نفر، رشته فيزيكى دو نفر،

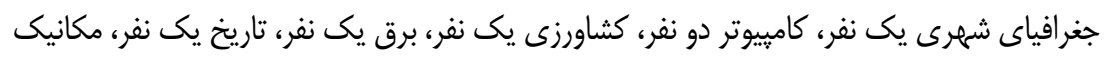
يك نفر، رياضى سه نفر، ادبيات يك نفر، شيمى سه نفر، و جامعهشناسى با يك نفر مصاحبه انجام شد.

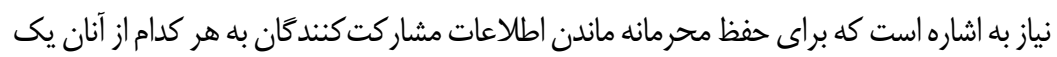
كد اختصاص مى يابد كه از اين به بعد، مشار كت كنندكان با اين كد شناخته مى شوند. از مشاركت كنندًان خواسته شد كه بر اساس تجربيات خود به اين يرسش ياسخ دهند كه نشانكان غنى سازى شغلى جيست.

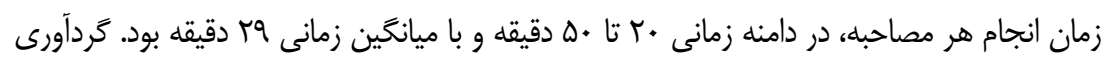

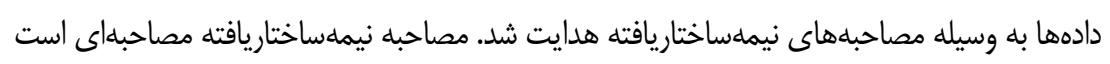

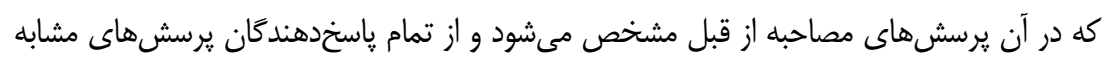


يرسيده مىشود، اما آنها آزاد هستند كه از هر راهى كه مىخواهند باسخ دهند. البته در راهنماى

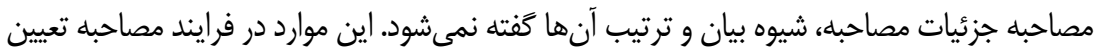

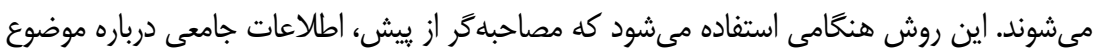

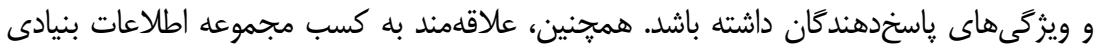

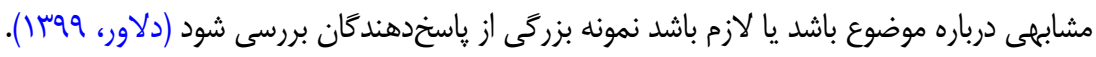

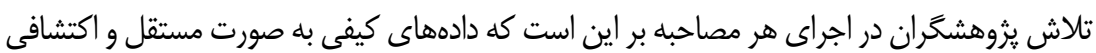

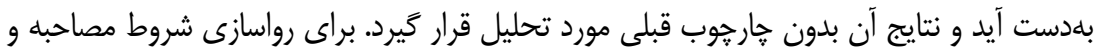

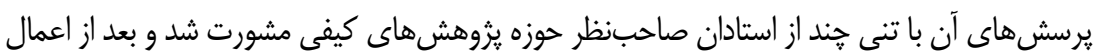
نظرهاى اصلاحى ايشان و اجراى نمونه مقدماتى، نسخه نهايى براى انجام مصاحبهها آماده كرديد.

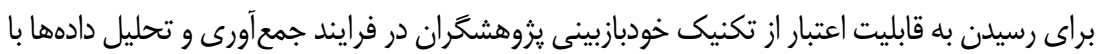

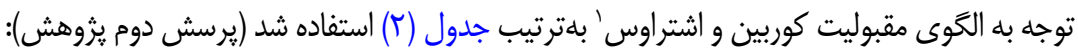

\section{جدول r: ارزيابى اتكايذيرى يافتهها}

\begin{tabular}{|c|c|}
\hline اقدامهاى صورت گرفته و نتايج & بار \\
\hline 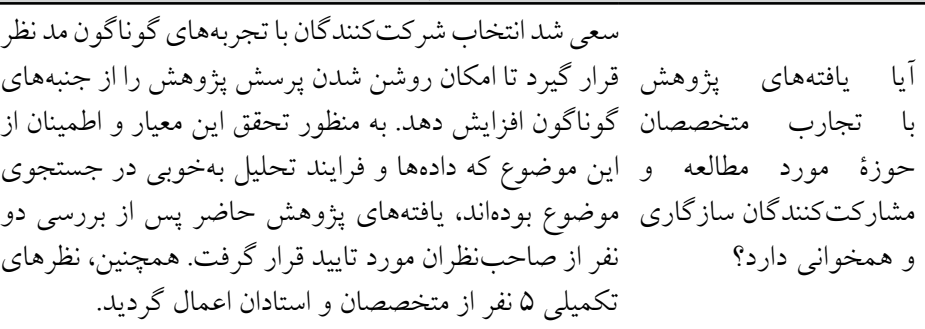 & تناسب \\
\hline 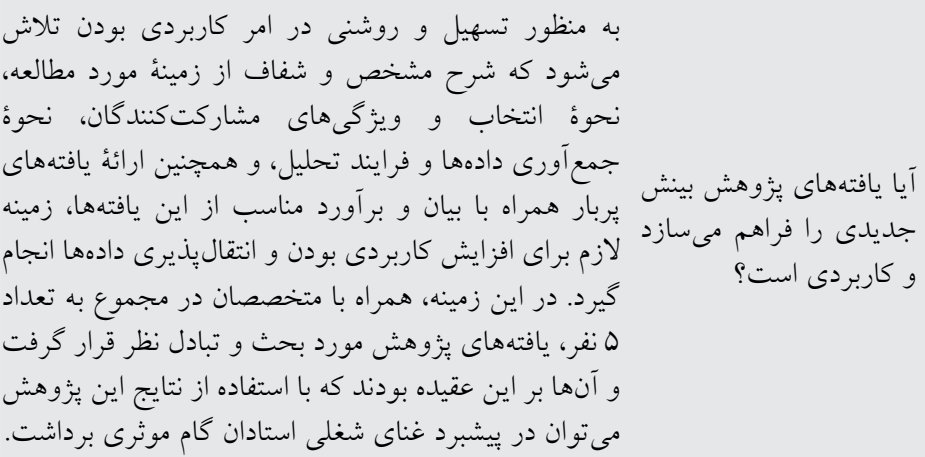 & كاربردى بودن مفيد بودن \\
\hline
\end{tabular}

1. Corbin \& Strauss 
ادامه جدول بَ: ارزيابى اتكايذيرى يافتهها

\begin{tabular}{|c|c|}
\hline اقدامهاى صورت گرفته و نتايج & 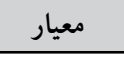 \\
\hline 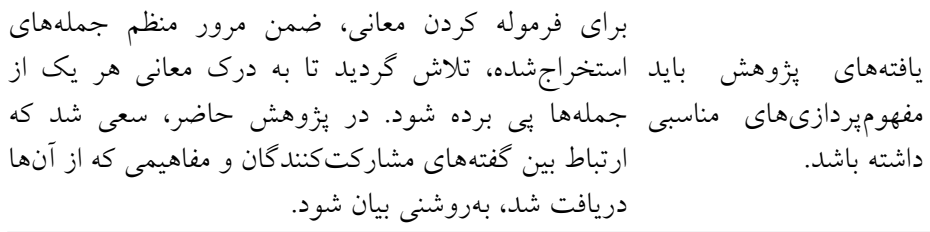 & مغاهيم \\
\hline 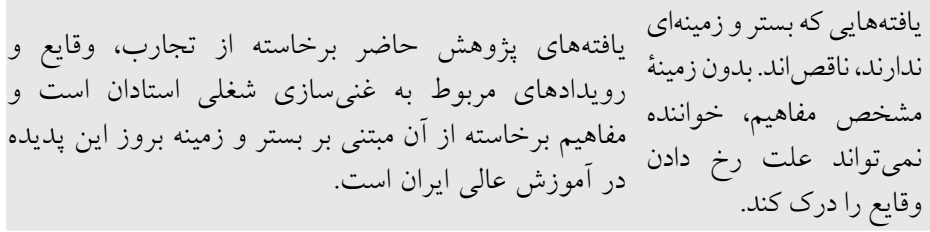 & زمينه مفاهيه. \\
\hline
\end{tabular}

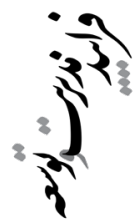

ابتدا خود يديده مورد بررسى قرار گرفت تا با شناخت ابعاد

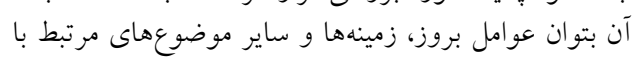

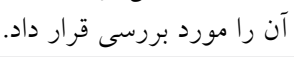

آياخطو ط داستان جريانهاى منطقى ترسيم مى كنند؟

منطق

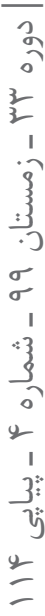

براى آشنايى با عمق و كستره دادهها، روايتهاى ارائهشده كه

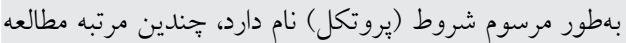

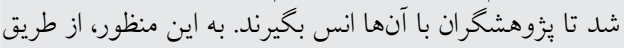

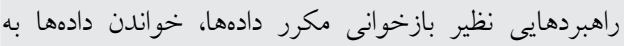

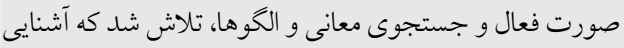

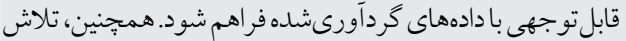
تشريح مفصل و مبسوط

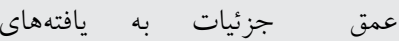
يزورهش غنا مى بخشئ.

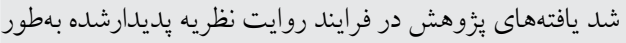

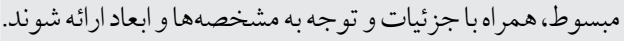

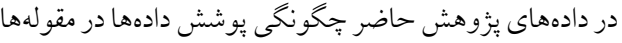

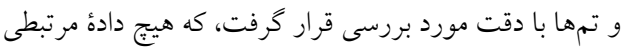

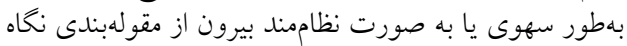

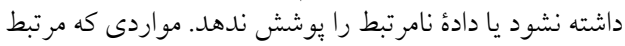

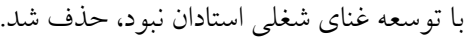

آيا يُزوهش حرف جديدى يافته هاى يُزوهش حاضر، براى ارائه مدل جامع و همه جانبه

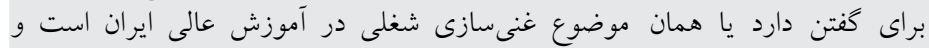

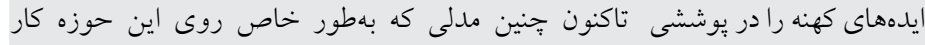


ادامه جدول ب: ارزيابى اتكايذيرى يافتهها

\begin{tabular}{|c|c|}
\hline اقدامهاى صورت گرفته و نتايج & معيار \\
\hline 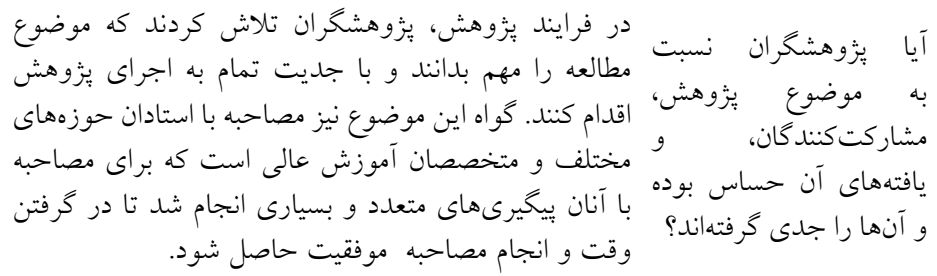 & كاسيت \\
\hline 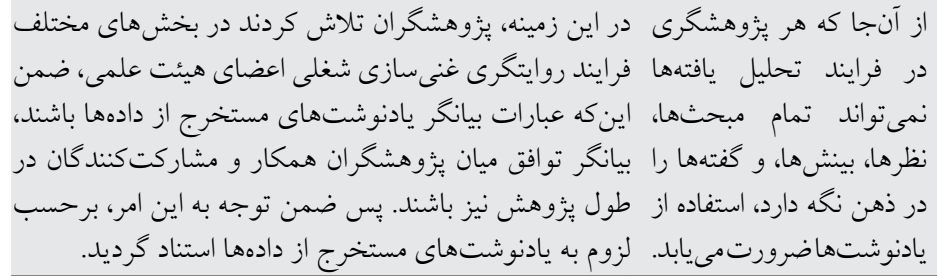 & يادنوشتهاد \\
\hline
\end{tabular}

همجنين براى ارتقاى اعتباريذيرى' يافتهها، از راهبرد كنترل از سوى اعضا' استفاده شد. بدين

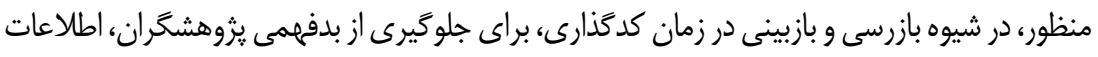
كسبشده دوباره در اختيار اطلاعرسانها قرار گرفت و از اعمال نظر نهايى آنان بهره گرفته شد.

\section{تجزيلووتحليل دادهها}

به منظور در ك كلى محتواى مصاحبهها، اطلاعات ضبطشده مشار كت كنندًان حروفنگًارى شدو به صورت مكتوب جمع آورى و جندين بار خوانده شد. سيس اين متن در اختيار نرمافزار MAXQDA قرار

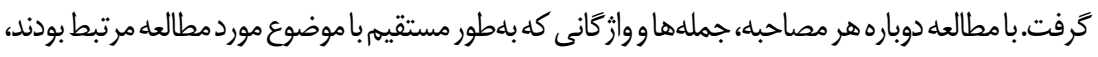

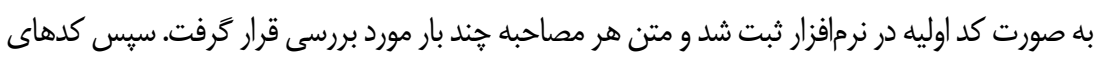

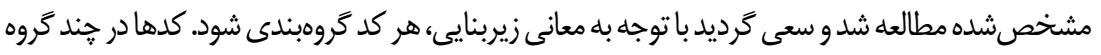
تقسيهبندى شدند. سيس براى هر گروه نامى تعيين شدو مصاحبه بعدى دقيقاً مطابق باهمين مراحل تكرار

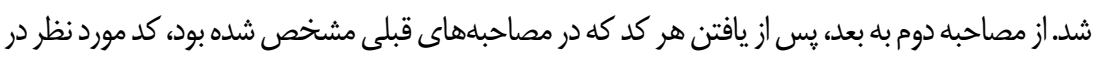
كد ثبتشده قبلى اضافه شد ودر صورتى كه كد يافتشده جديد بود، به فهرست كدهاى موجود در نرمافزار

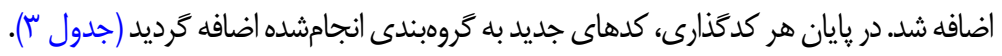

1. Credibility

2. Member Check 
جدول بّ: كدها، مفاهيم، و مقولههاى يزوهش

\begin{tabular}{|c|c|c|}
\hline تعداد مقوله & تعداد كد & نوع مقوله \\
\hline 9 & r^ & آموزشى \\
\hline i & 11 & يزّوهشى \\
\hline q & 19 & ارائه خدمات تخصصى \\
\hline$\Delta$ & 11 & ويزگ گى هاى فردى \\
\hline r & pre & ويز گیى هاى سازمانى \\
\hline זץ & IT. & جمع \\
\hline
\end{tabular}

از ميان • rا كد باز (جدول r) كه خروجى دادههاى گردآورىشده بود، در مجموع سץ مقوله يديدار گَرديد (يرسش اول يزوهش)، كه مدل نهايى بر اساس آن استخراج گَرديد (جدول ؟أ).

جدول f: ماتريس كيفى مقولههاى استخراجشده

\begin{tabular}{|c|c|c|c|}
\hline 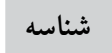 & مقولههاى منتخب & \multicolumn{2}{|c|}{ كدهاى محورى (مقولهها) شناسه } \\
\hline$\overline{\mathrm{A} 1 \mathrm{CO} 1}$ & تسلط به كاربرد روشهاى نوين و خلاقانه تدريس & \multirow{6}{*}{$\mathrm{A} 1 \mathrm{CO}$} & \multirow{6}{*}{ 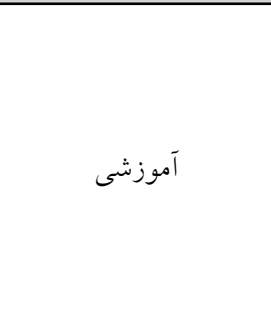 } \\
\hline $\mathrm{A} 1 \mathrm{CO} 2$ & يويايى گرى استاد & & \\
\hline $\mathrm{A} 1 \mathrm{CO} 3$ & انديشهسازى جريان آموزش & & \\
\hline $\mathrm{A} 1 \mathrm{CO} 4$ & توان تدوين راهبردهاى آموزشى و ارزشيابى & & \\
\hline $\mathrm{A} 1 \mathrm{CO} 5$ & توانايى ارائه بازخورد و تفكر انعكاسى & & \\
\hline A1CO6 & ايجادكننده اهداف برتر يادگيرى در مخاطبان & & \\
\hline $\mathrm{R} 1 \mathrm{CO} 1$ & حساسيت به جمع آورى دادههاى صحيح & \multirow{4}{*}{$\mathrm{R} 1 \mathrm{CO}$} & \multirow{4}{*}{ 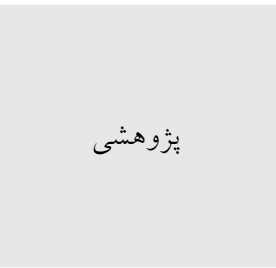 } \\
\hline $\mathrm{R} 1 \mathrm{CO} 2$ & مهارت تيمسازى و شبكهسازى (ملّى و بينالمللى) & & \\
\hline $\mathrm{R} 1 \mathrm{CO} 3$ & قدرت مديريت بروزه & & \\
\hline $\mathrm{R} 1 \mathrm{CO} 4$ & 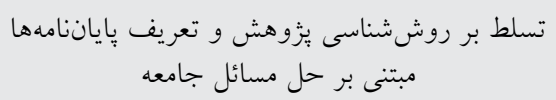 & & \\
\hline S1CO1 & مهارت كارآفرينى و خلق ثروت & \multirow{4}{*}{$\mathrm{S} 1 \mathrm{CO}$} & \multirow{4}{*}{ ارائه خدمات تخصصى } \\
\hline $\mathrm{S} 1 \mathrm{CO} 2$ & توانايى حل مسائل كاربردى جامعه & & \\
\hline $\mathrm{S} 1 \mathrm{CO} 3$ & ارتباط با اجتماع و صنعت & & \\
\hline $\mathrm{S} 1 \mathrm{CO} 4$ & قدرت كفتمانسازى & & \\
\hline
\end{tabular}


ادامه جدول f: ماتريس كيفى مقولههاى استخر اجشده

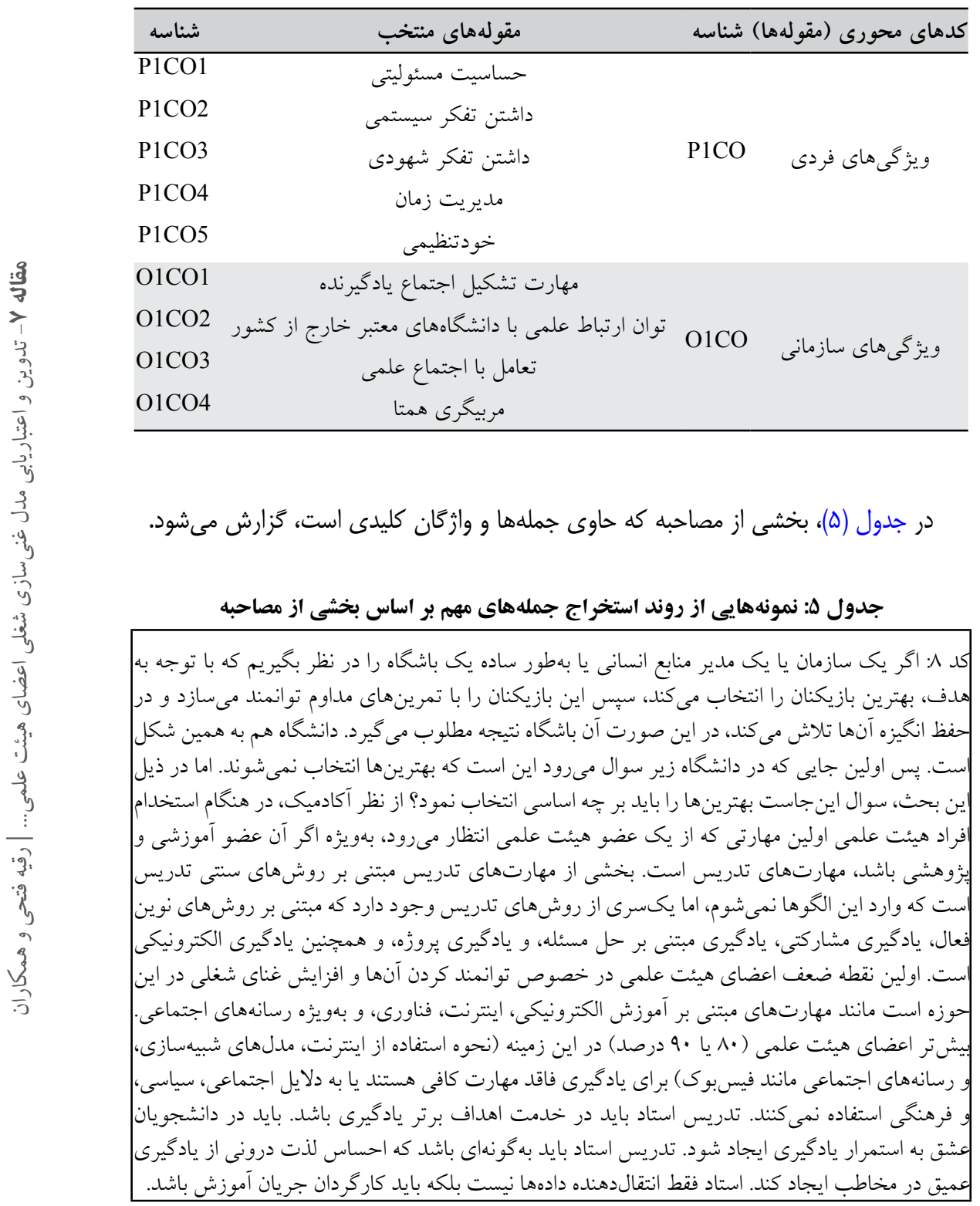


ادامه جدول ه: نمونههايى از روند استخراج جملههاى مهم بر اساس بخشى از مصاحبه

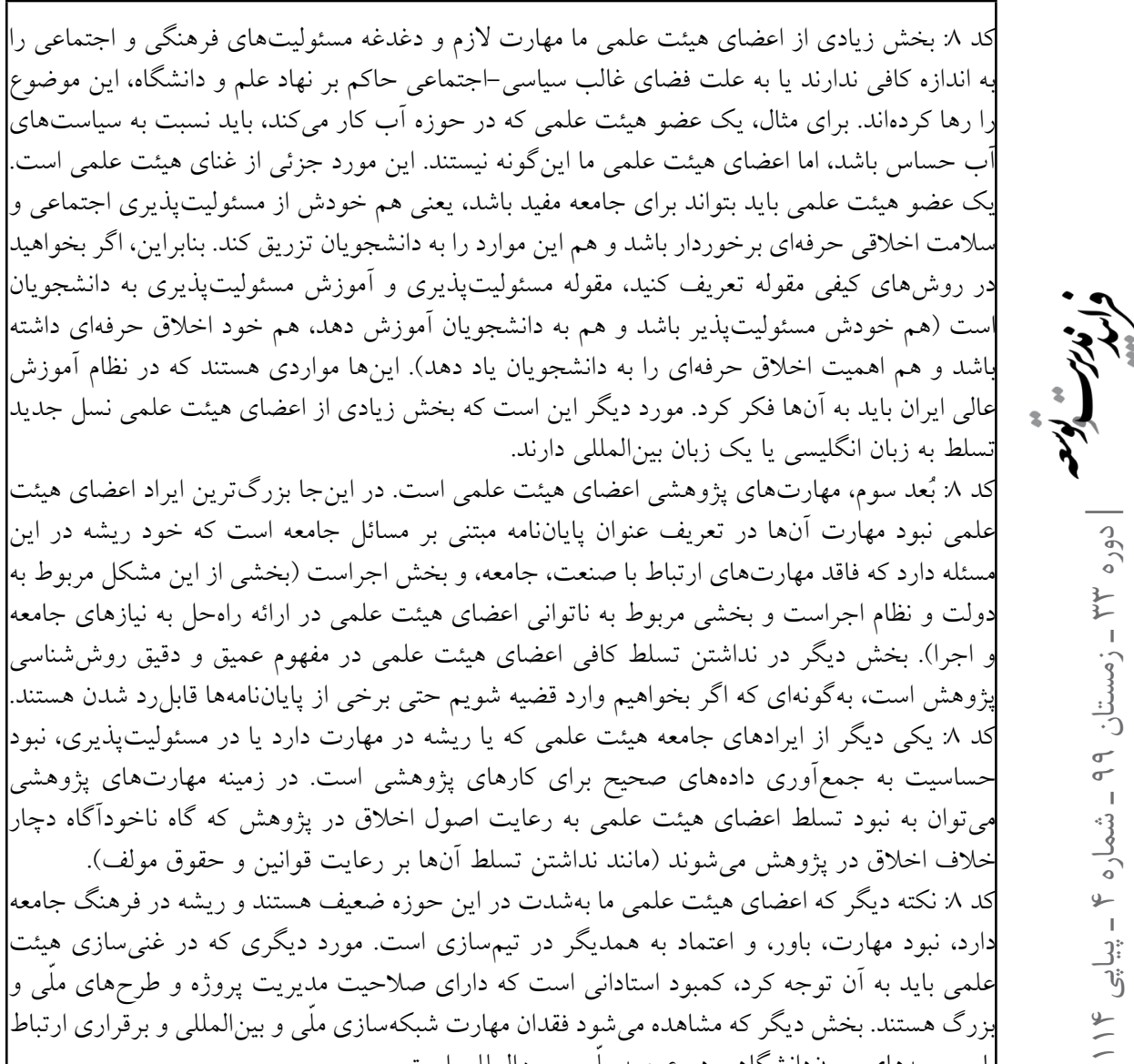

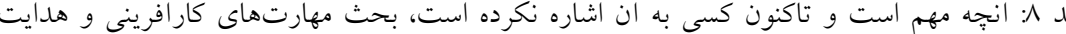

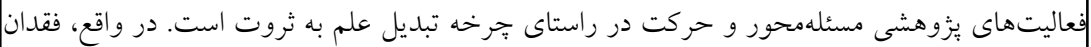

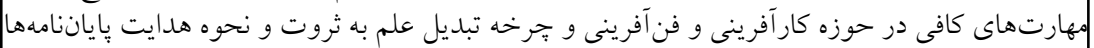

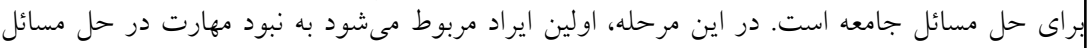

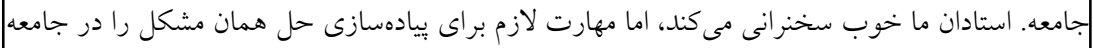

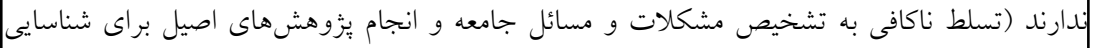

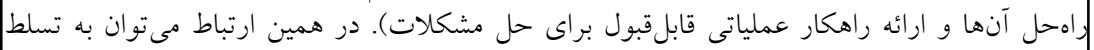

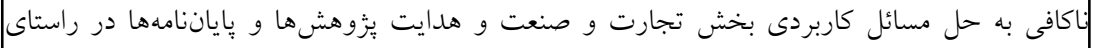

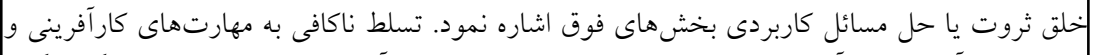

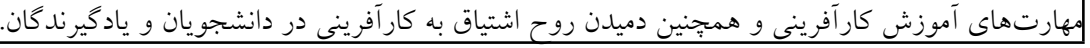


ادامه جدول ه: نمونههايى از روند استخراج جملههاى مهم بر اساس بخشى از مصاحبه

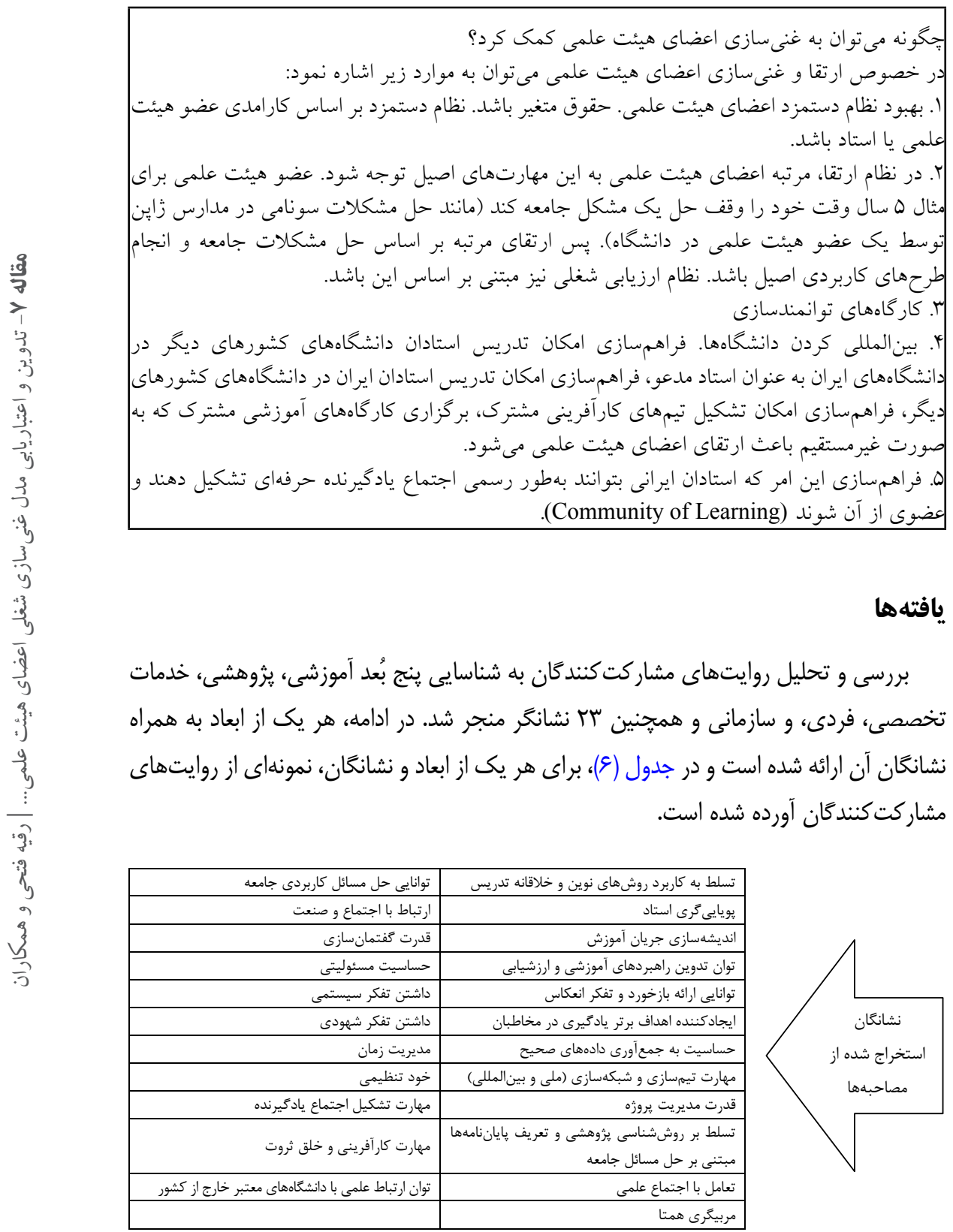

شكل 1. نشانكرهاى منتج شده از مصاحبهها 


لبُعد

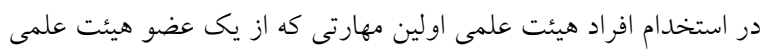

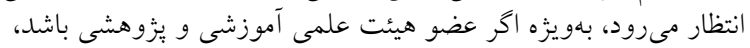

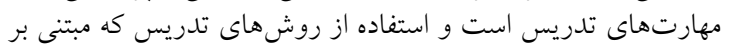

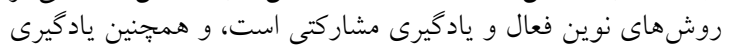

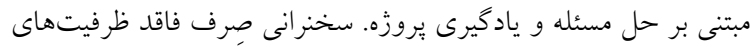

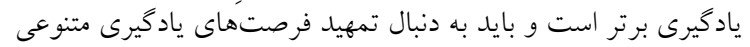
تسلط به كاربرد

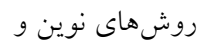
خلاقانه تدريس نوين

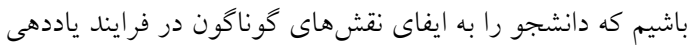

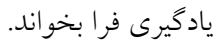

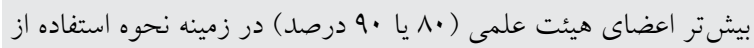

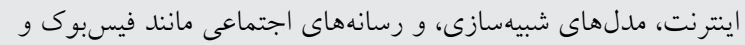

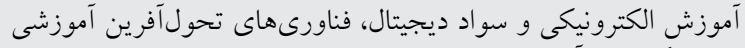

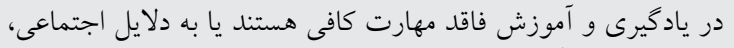
يويايى گرى استاد

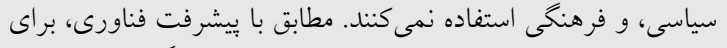

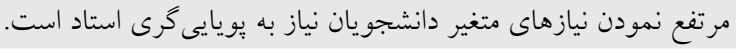

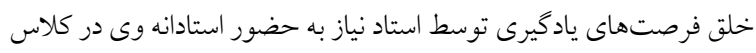

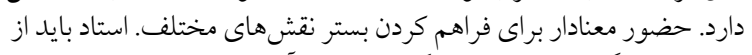

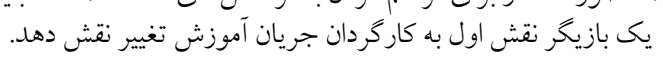

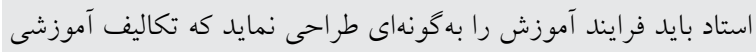

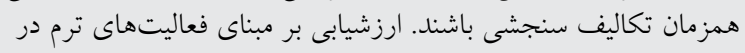

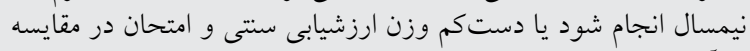

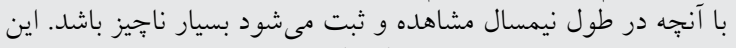

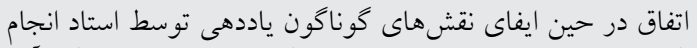

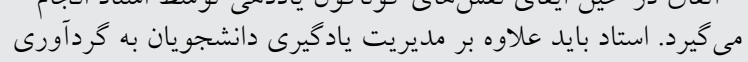

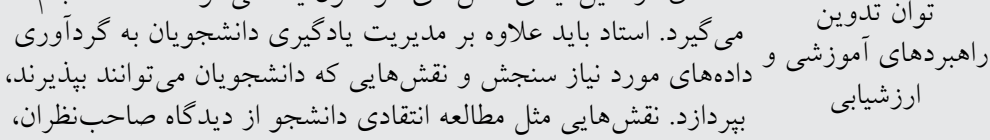
ارزشيابى آمز

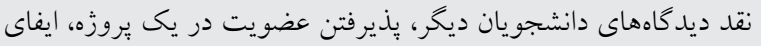

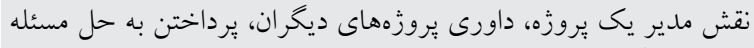

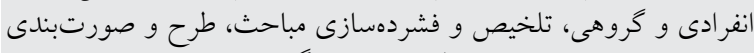

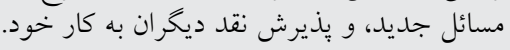

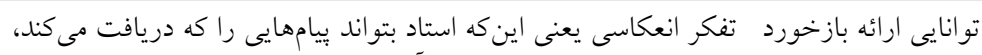

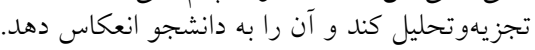
و تفكر انعكاسى توانى

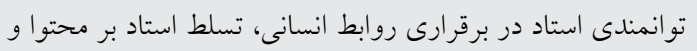

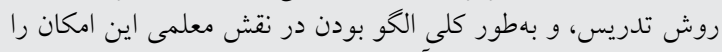

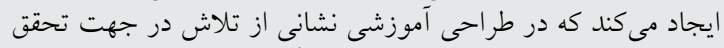

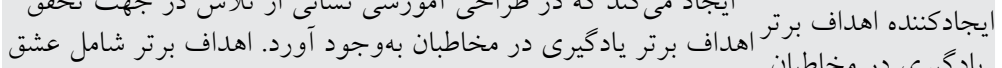

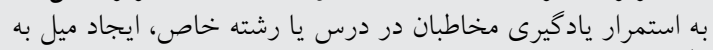
ياد يرى در مخاطبان آموزشى

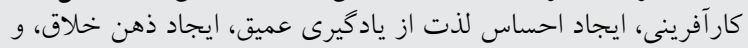

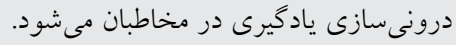




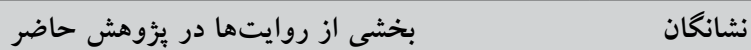

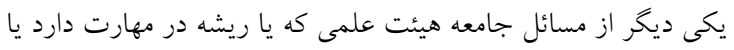

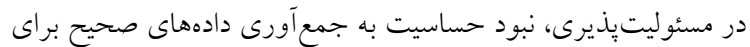

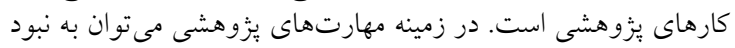

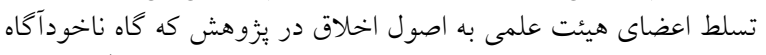

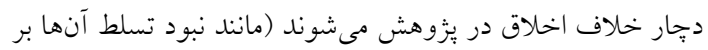

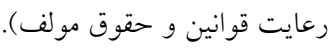

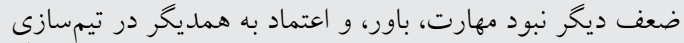

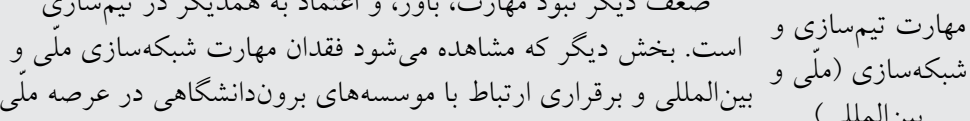

$$
\text { و بين المللى است. }
$$

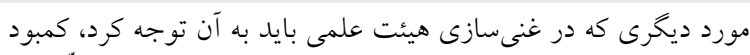

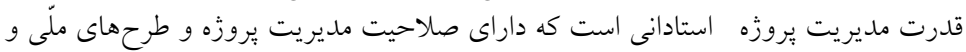
بزرى هستند.

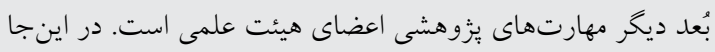

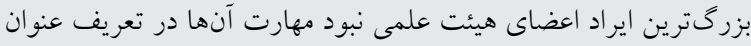

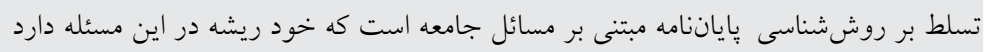

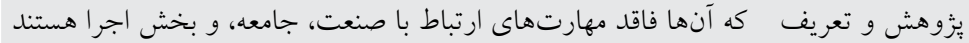

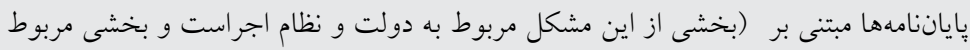

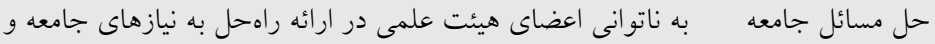

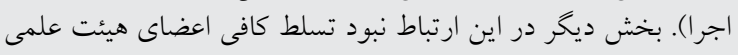

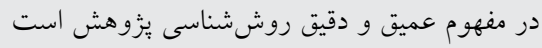

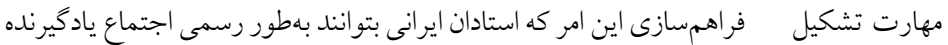

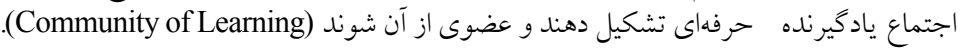

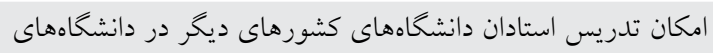

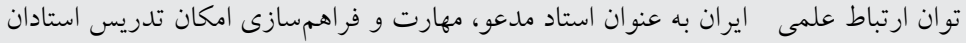

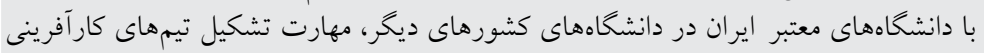

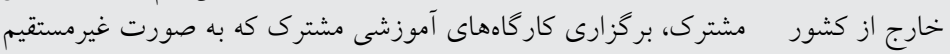
باعث ارتقاى اعضاى هيئت علمى مى أشود.

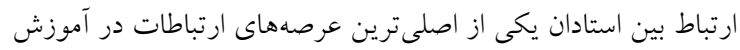

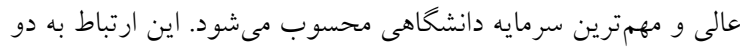

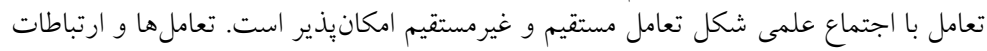

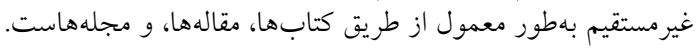

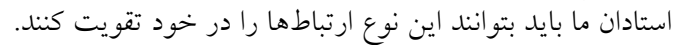


ادامه جدول \&: ابعاد، نشانكان، و بخشى از روايتهاى ثزوهش حاضر

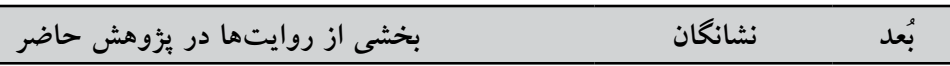

من معتقل هستم كه هر استاد مسئوليت رشد حرفهاى خود را بر عهلده دارد

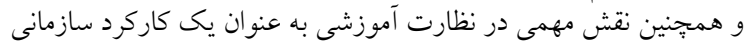

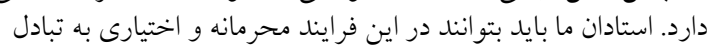

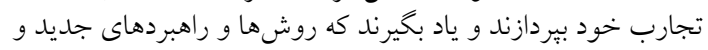
مربيخرى همتا

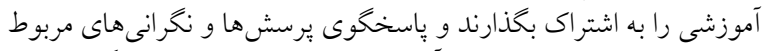

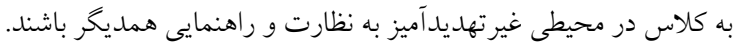
اولين مهارت يكى عضو هيئت علمى، مهارتهاى تدريس است. او باو

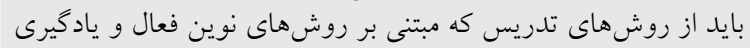

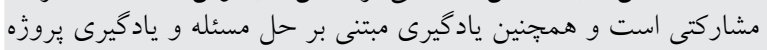

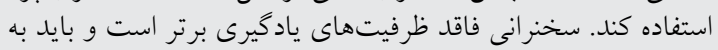

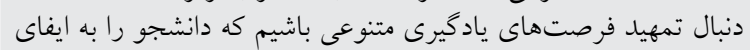
تسلط بـه كاربرد

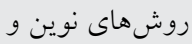
خلاقانه تدريس نوين سازمانى

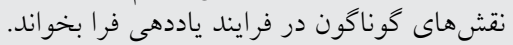

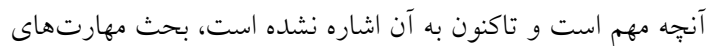

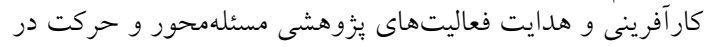

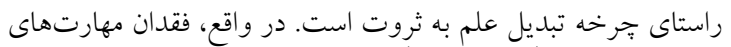

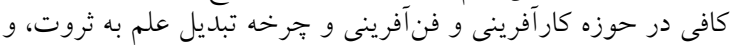

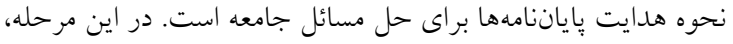

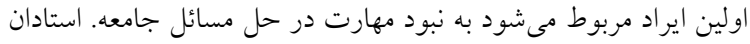

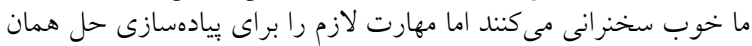

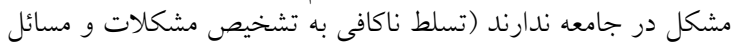

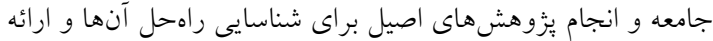
مهارت كارآفينى و خلق ثروت

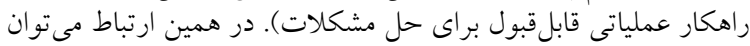

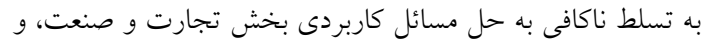

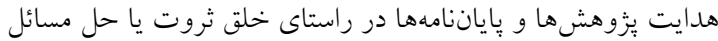

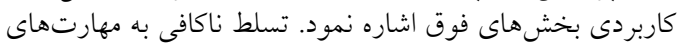

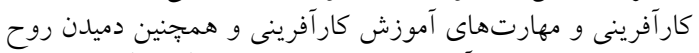
ارائه خدمات

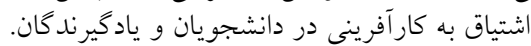

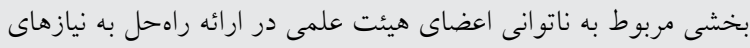

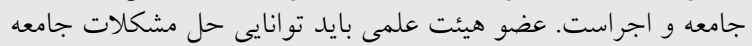

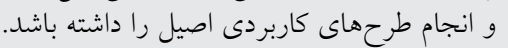

توانيى حل مسائل كاربردى جامع حت

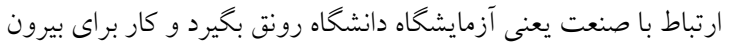

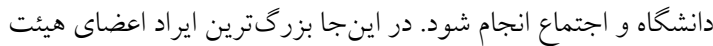

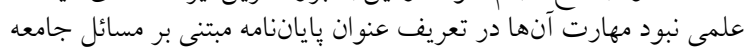

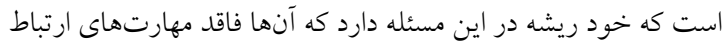

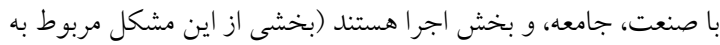
ارتباط با اجتماع و

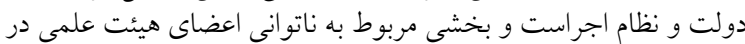
صنعت

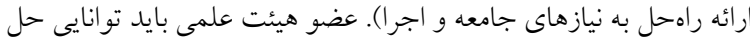

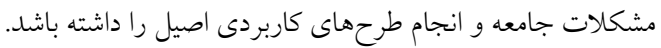




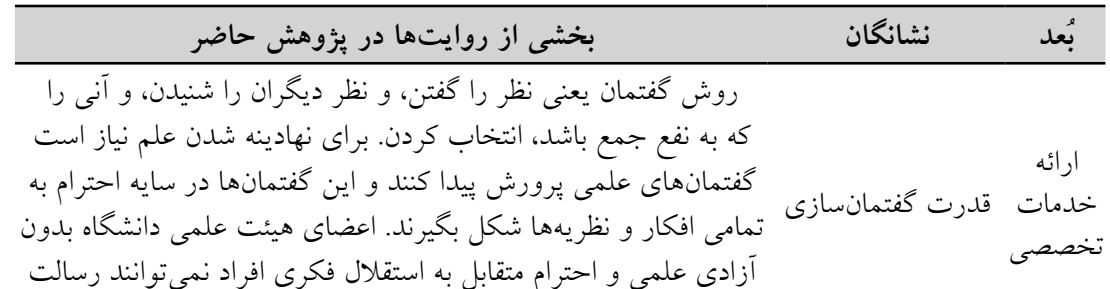
خود و دانشخاه را بهدرستى انجام دهند.

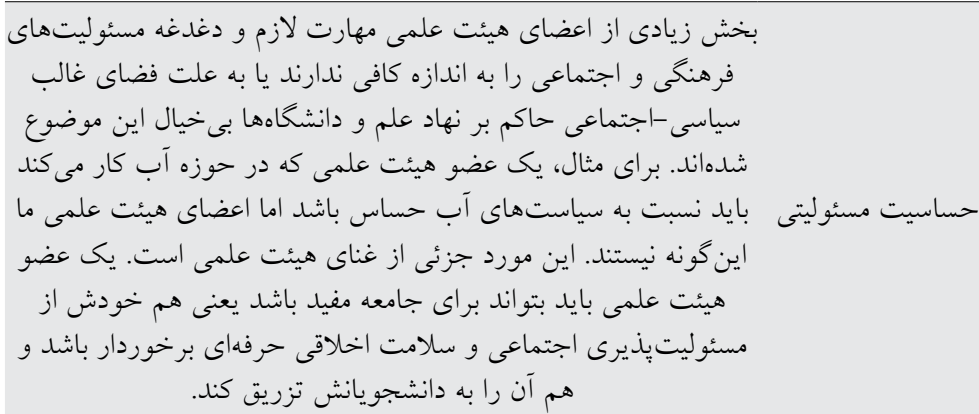

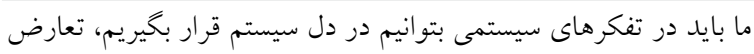

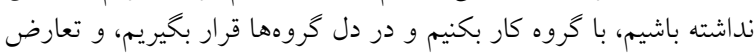

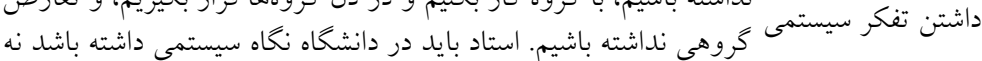

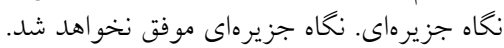

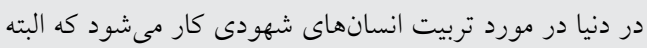

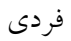

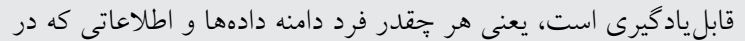

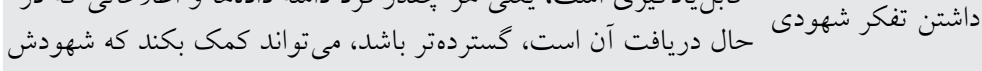
هم افزايش يابد.

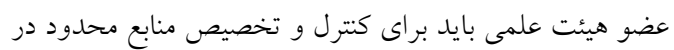

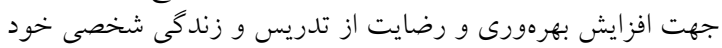

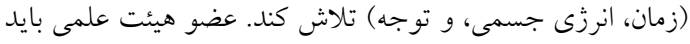

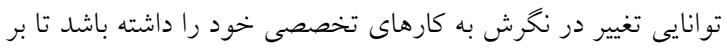
مديريت زمان

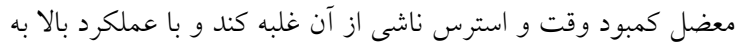

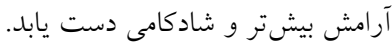

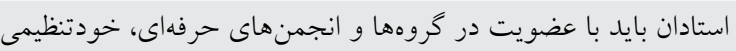

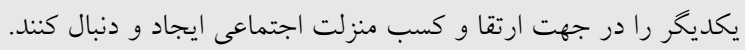

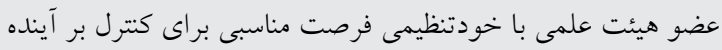


در ادامه، نماى بصرى ابعاد و نشانغان در شكل (1) آورده شده است:

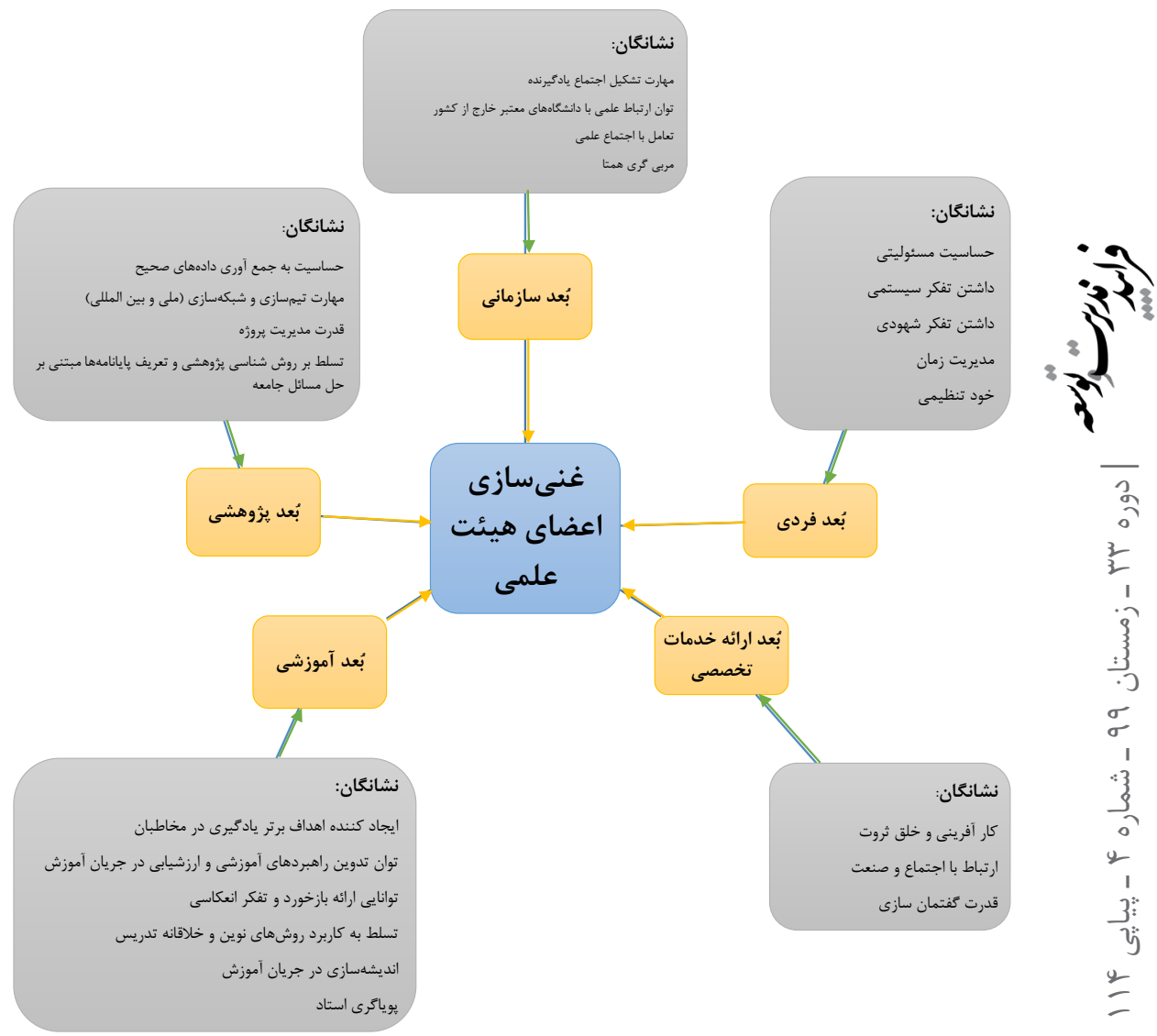

شكل 1: مدل نشانكان و ابعاد غنى سازى شغلى اعضاى هيئت علمى (يرسش دوم يزووهش)

\section{بحث و نتيجه تيرى}

يزوهش حاضر با هدف تدوين و اعتباريابى مدل غنىسازى شغلى اعضاى هيئت علمى انجام كرديد. بر اساس نتايج، نشانغان غنىسازى شغلى اعضاى هيئت علمى شامل ينج بُعد آموزشى،

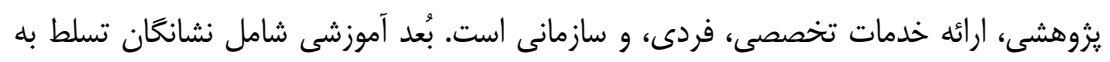
كاربرد روشهاى نوين و خلاقانه تدريس، يويايى 
تدوين راهبردهاى آموزشى و ارزشيابى در جريان تدريس، توانايى ارائه بازخورد و تفكر انعكاسى،

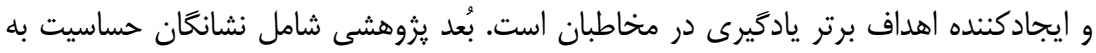

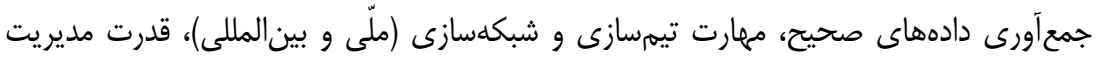
يروزه، و تسلط بر روششناسى يزوهش و تعريف پاياننامهها مبتنى بر حل مسائل جامعه است.

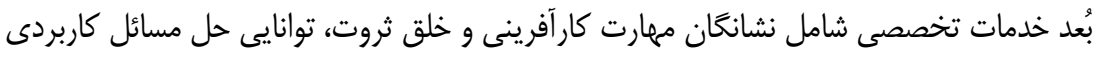

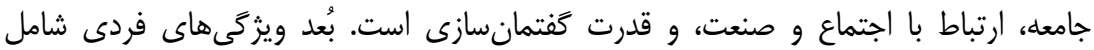
نشانكان حساسيت مسئوليتى، تفكر سيستمى، تفكر شهودى، مديريت زمان، و خودتنظيمى است.

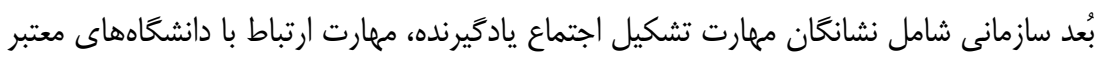
خارج كشور، تعامل با اجتماعهاى علمى، و مربيكرى همتاست. قابليتهاى آموزشى كه از مهمترين قابليتهاى مورد نياز اعضاى هيئت علمى است شامل هامل هاسل مهارتهاى تدريس، مديريت كلاس درس، و كاربست اصول تربيتى است. الكياوى و عزالدين

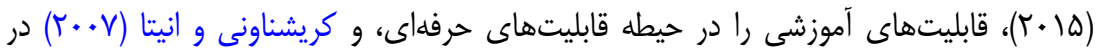

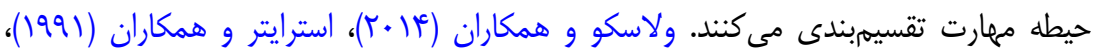

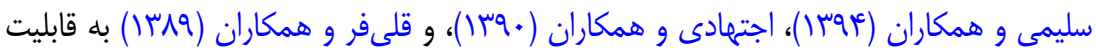
تدريس به عنوان يكى از مهمترين قابليتهاى اعضاى هيئت علمى اشاره دارند. مشار كت كنندًان در يروهش نيز قابليتهاى آموزش و تدريس را از مهمترين قابليتهاى اعضاى هيئت علمى و

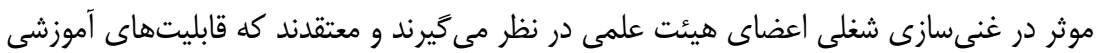

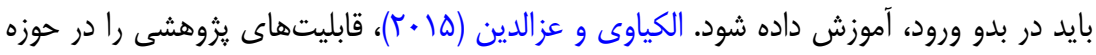

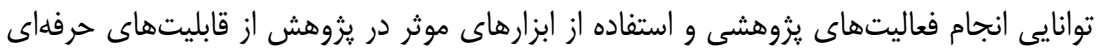

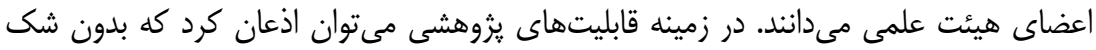

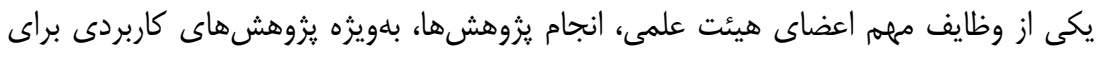

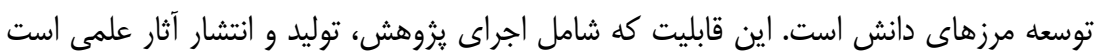

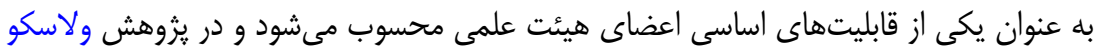

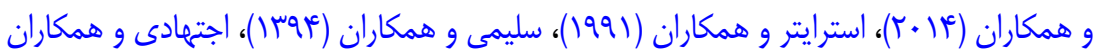

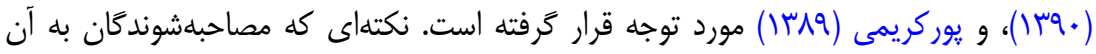

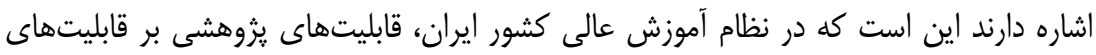

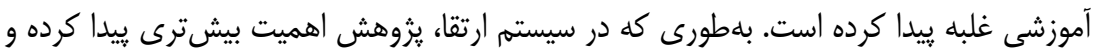
سبب شده برخى اوقات به رسالت آموزش دانشخاهها كه يكى از اصلىترين اهداف دانشخاههاست، 
ضربئ جبران نايذيرى وارد شود. قابليتهاى تخصصى نيز كه شامل تسلط بر ابعاد دانش تخصصى

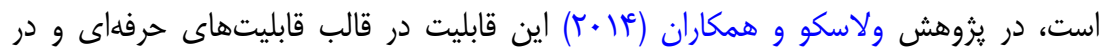

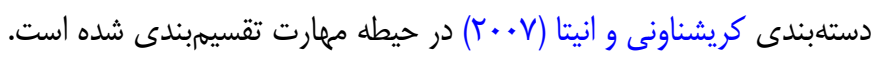
نشانكان فردى و سازمانى تحت عنوان اخلاق حرفهاى در يزوهشهاى ديخر مورد بررسى

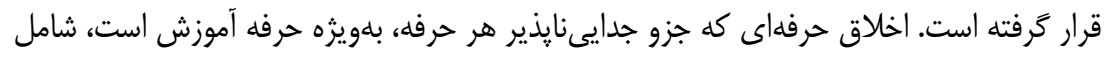

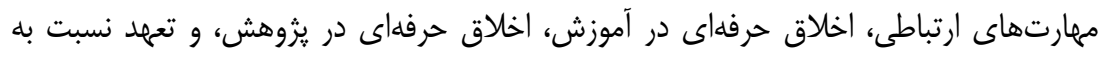

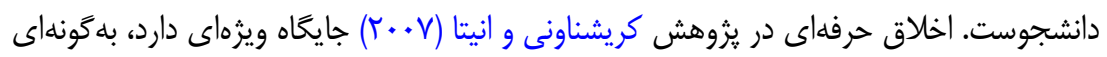

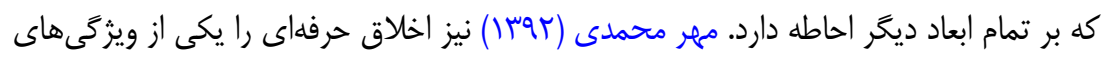

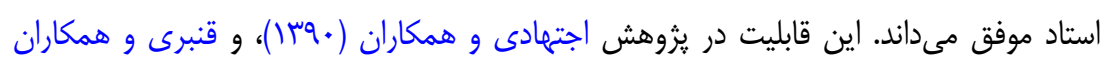

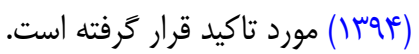

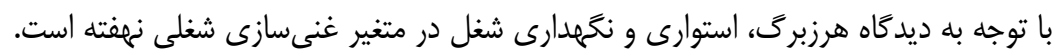

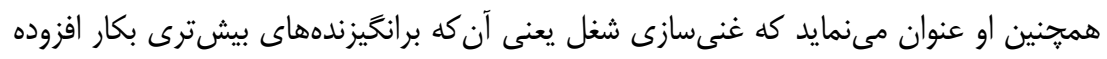

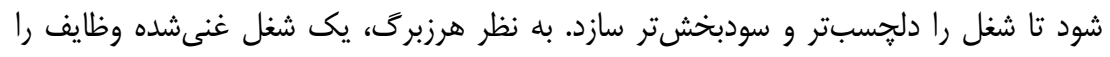

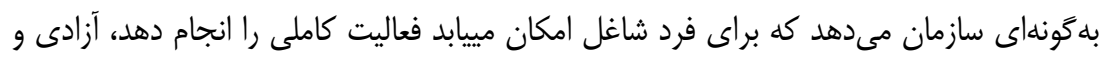

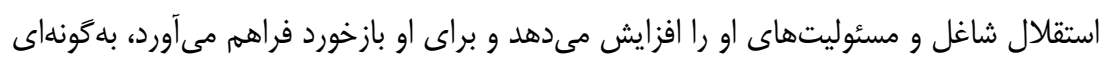

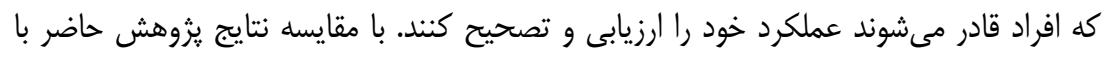

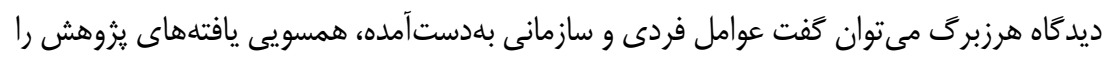

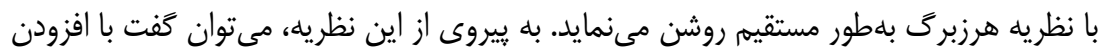

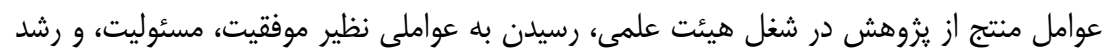
استادان بيشتر محتمل خواهد شد.

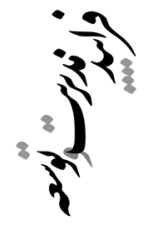

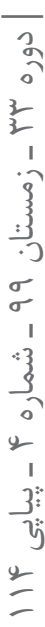

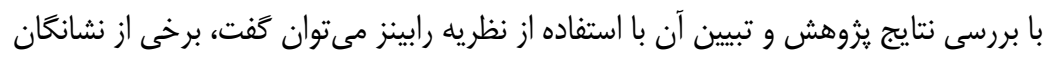

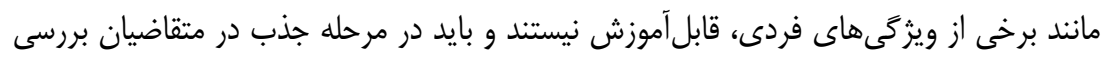

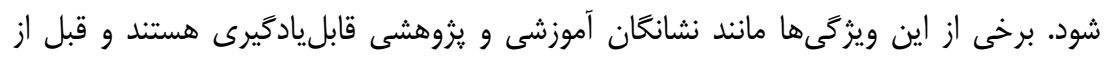

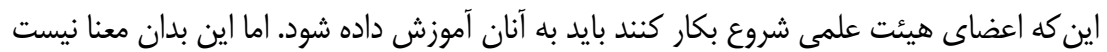

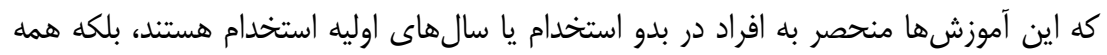

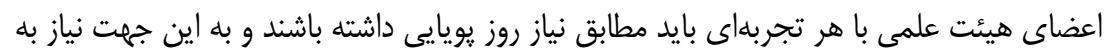

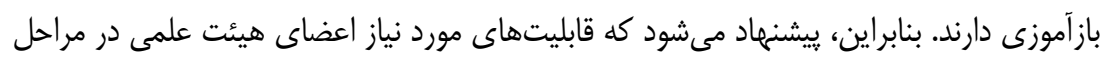

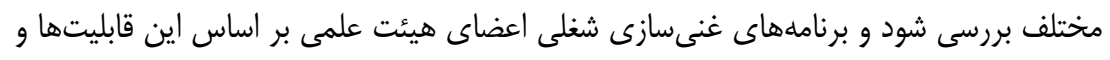


براى همه اعضاى هيئت علمى متناسب با نيازها و قابليتهاى مورد نياز طراحى و اجرا كردد. در اين راستا و در جهت ارتقاى غنىسازى شغلى اعضاى هيئت علمى و بهبود وضعيت علمى دانشكاهها،

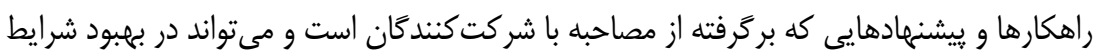
موجود راهخشا باشد، ارائه مى شود:

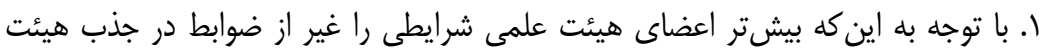

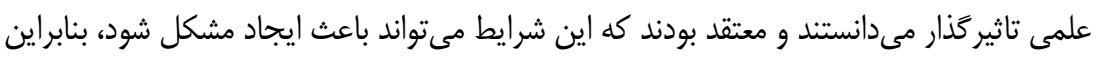
ييشنهاد مىشود در جذب هيئت علمى، اقتضاهاى دانشى، مهارتى، صفات، اخلاق حرفهاى، و توان

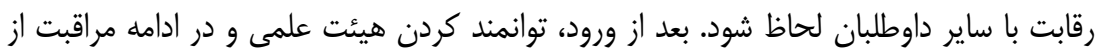

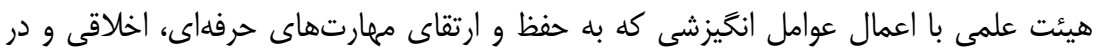
نهايت غنىسازى شغلى او منجر مى شود، در دستور كار دانشخاه قرار كيرد.

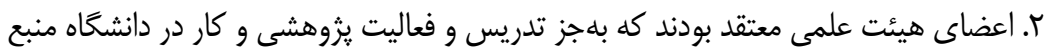

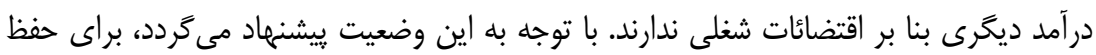

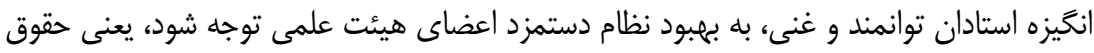
متغير باشد و نظام دستمزد بر اساس كارامدى عضو هيئت علمى يا استاد باشد. بأندا.

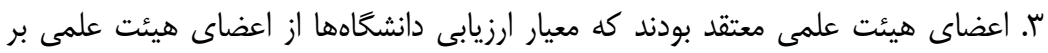

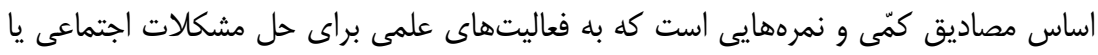

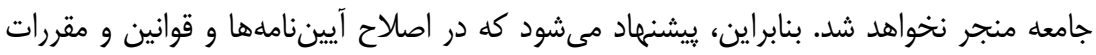
نظام ارتقا، مرتبه اعضاى هيئت علمى به شاخصهاى كيفى و يرهيز از كمّى ترايى صرف، بهائ

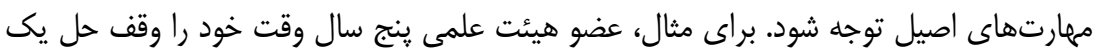

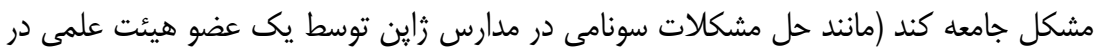

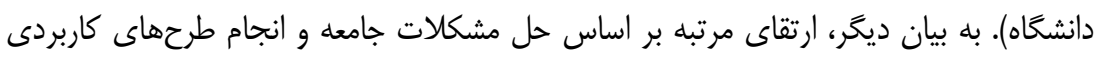

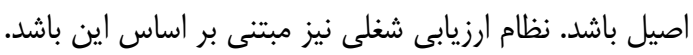

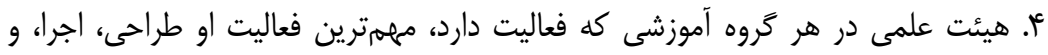

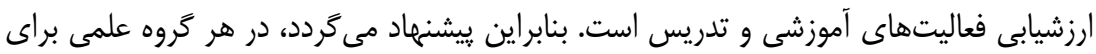

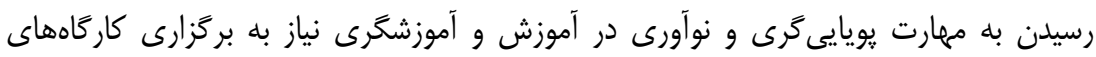

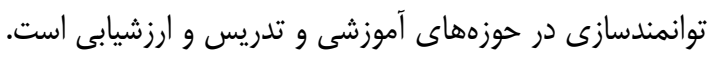

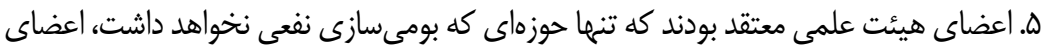

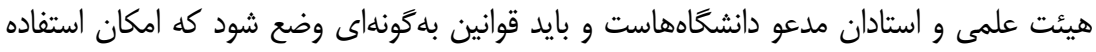


از استادان ساير دانشخاهها و مراكز علمى فراهم شود. بنابراين بيشنهاد مى گردد، بخش اجرايى به بينالمللى كردن دانشگاهها، فراهمسازى امكان تدريس استادان دانشكاههاى كشورهاى ديخر دران دانشخاههاى ايران به عنوان استاد مدعو، فراهمسازى امكان تدريس استادان ايران در دانشخاههاى

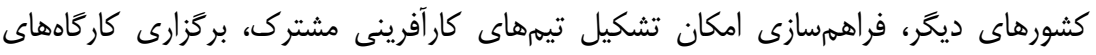

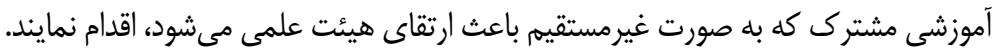
و امروزه استفاده از دانش يا بهاصطلاح همافزايى هوشى و دانشى امرى ضرورى است.

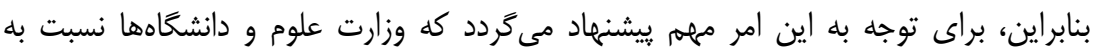

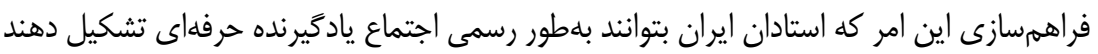
و عضوى از آن شوند، اقدام نمايند.

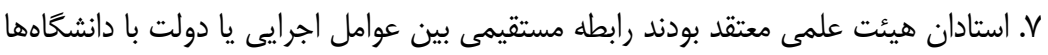

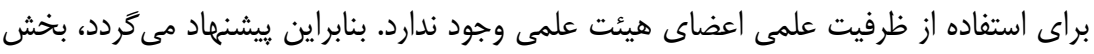

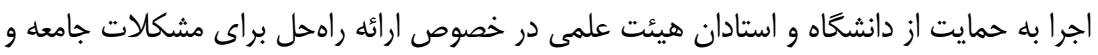
يذيرش طرحهاى اجتماعى و ملّى توجه نمايند.

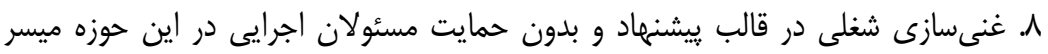

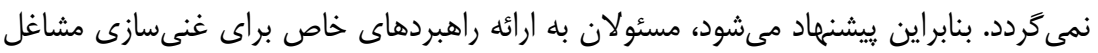

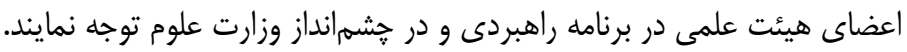

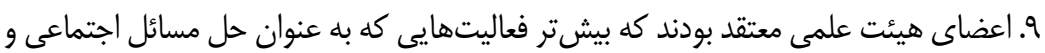

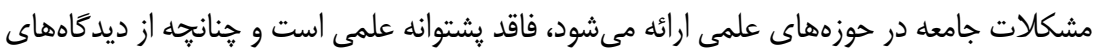

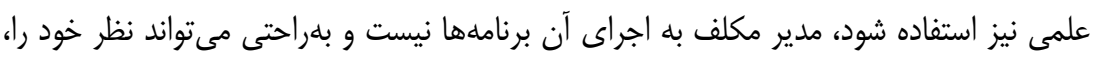

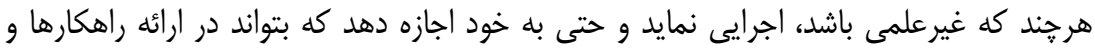

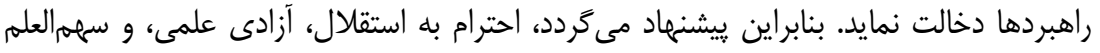
داشتن اعضاى هيئت علمى در ساختارها و سياستهاى كلان كشور مد نظر قرار كيرد.

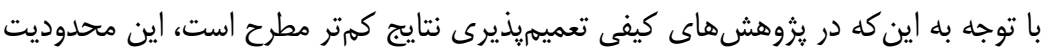

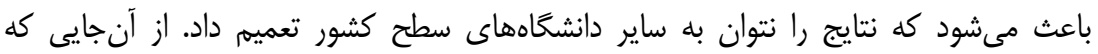

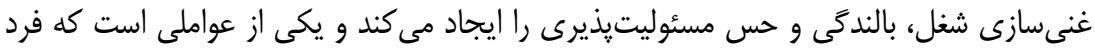

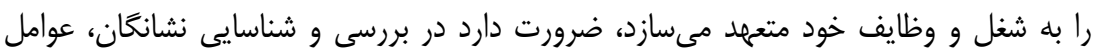
تاثيركذار و بازدارنده غنىسازى شغلى اعضاى هيئت علمى براى ايجاد تحول بيشتر در اين حوزه، يزوهشهاى مشابه در ساير دانشكاههاى كشور انجام يذيرد. 


\section{منابع}

\section{الف) فارسى}

اجتهادى، مصطفى؛ قورجيان، نادرقلى؛ جعفرى، يريوش، و شفيعزاده، حميد (•وسا). شناسايى ابعاد و

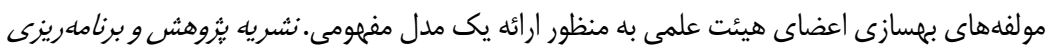

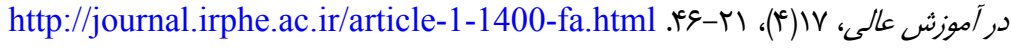

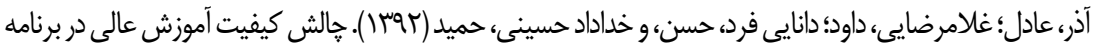

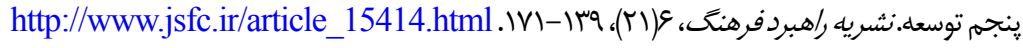

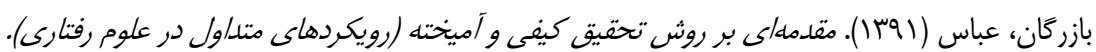
انتشارات ديدار. باقريان، فاطمه (سرس ا). نظام آموزش عالى كانادا، دايرهالمعارف آموزش عالى (جلد دوم). انتشارات بنياد

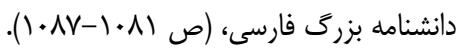

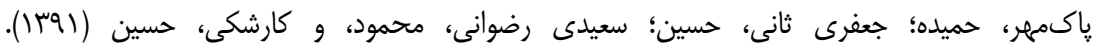

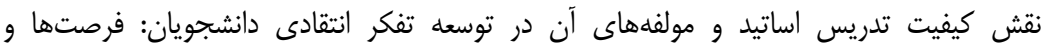

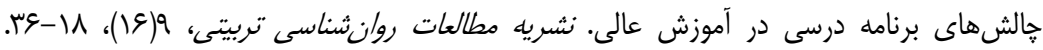
https://dx.doi.org/10.22111/jeps.2012.1037

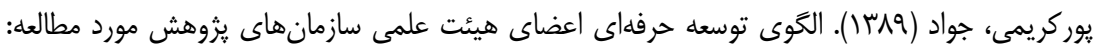

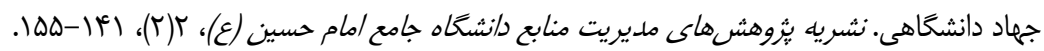

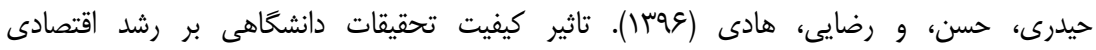

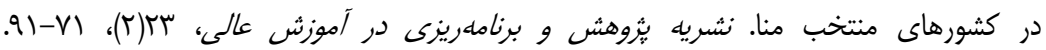
http://journal.irphe.ac.ir/article-1-3307-fa.html

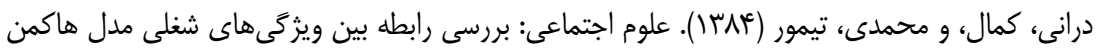

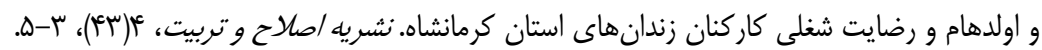

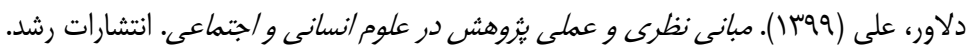

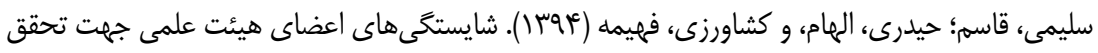

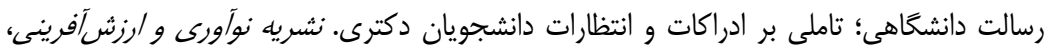
س عبدالهى، بيثن، و حيدرى، سريه (VM (IM). عوامل مرتبط با توانمندسازى اعضاى هيئت علمى دانشخاه:

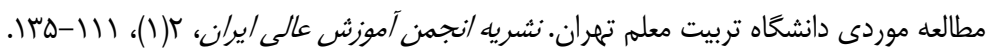

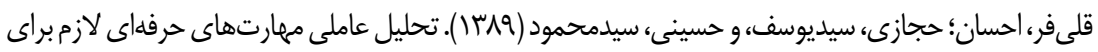

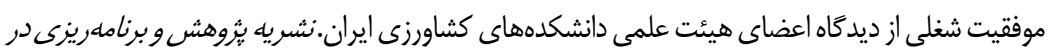

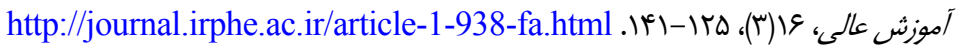

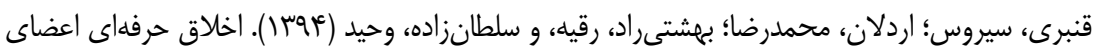

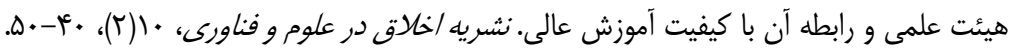




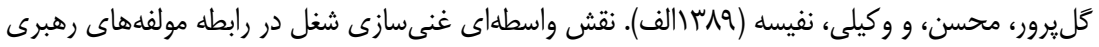

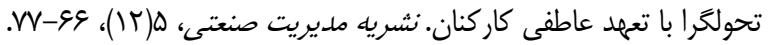

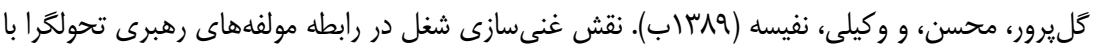

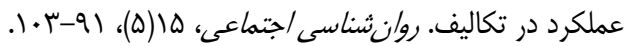

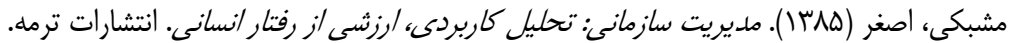

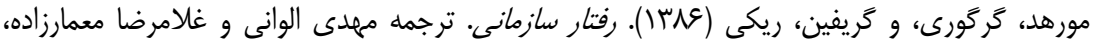

$$
\text { انتشارات مرواريد. }
$$

موسوى، الهها (عمب()). غنىسازى شغلى راه رهايى سازمانها و كاركنان از ديوانسالارى. نشريه بهداشت

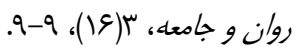

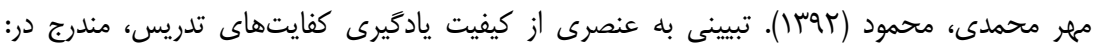

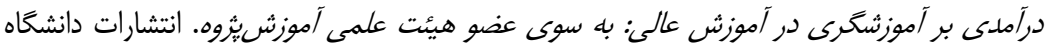

$$
\text { تربيت مدرس. }
$$

مير كمالى، سيدمحمد؛ يور كريمى، جواد، و حجرى، اكرم (أوج"ا(). بررسى رابطه توسعه حرفهاى با نوآورى آموزشى

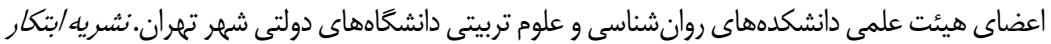

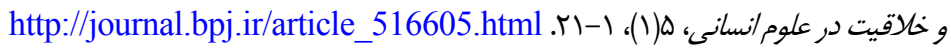

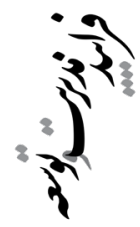

Alexander, A., Karvonen, M., Ulrich, J., Davis, T., \& Wade, A. (2012). Community College Faculty Competencies. Community College Journal of Research and Practice, 36(11), 849-862. https://doi.org/10.1080/10668926.2010.515511

Alqiawi, D. A., \& Ezzeldin, S. M. (2015). A Suggested Model for Developing and Assessing Competence of Prospective Teachers in Faculties of Education. World Journal of Education, 5(6), 65-73.

Alstete, J. W. (2000). Posttenure Faculty Development: Building a System for Faculty Improvement and Appreciation. ASHE-ERIC Higher Education Report, 27(4). Jossey-Bass Higher and Adult Education Series: ERIC.

Barnett, R. (2001). Managing Universities in a Supercomplex Age. Chaos Theory and Higher Education: Leadership, Planning and Policy, 13-32.

Gappa, J. M. (2008). Today's Majority: Faculty Outside the Tenure System. Change: The Magazine of Higher Learning, 40(4), 50-54. https://doi.org/10.3200/CHNG.40.4.50-54

Hyatt, L., \& Williams, P. E. (2011). 21st Century Competencies for Doctoral Leadership Faculty. Innovative Higher Education, 36(1), 53-66. https://doi.org/10.1007/s10755-010-9157-5

Krishnaveni, R., \& Anitha, J. (2007). Educators' Professional 
Characteristics. Quality Assurance in Education, 15(2), 149-161. https://doi.org/10.1108/09684880710748910

Malik, N. (2010). A Study on Motivational Factors of the Faculty Members at University of Balochistan. Serbian Journal of Management, 5(1), 143-149.

McNall, L. A., Masuda, A. D., \& Nicklin, J. M. (2009). Flexible Work Arrangements, Job Satisfaction, and Turnover Intentions: The Mediating Role of Work-To-Family Enrichment. The Journal of Psychology, 144(1), 61-81. https://doi.org/10.1080/00223980903356073

Mulili, B. M., \& Wong, P. (2011). Continuous Organizational Development (COD). Industrial and Commercial Training, 43(6), 377-384. https://doi.org/10.1108/00197851111160513

Oldham, G. R., \& Hackman, J. R. (2010). Not What It Was and Not What It Will Be: The Future of Job Design Research. Journal of Organizational Behavior, 31(2-3), 463-479. https://doi.org/10.1002/job.678

Salau, O. P., Adeniji, A., \& Oyewunmi, A. E. (2014). Relationship between Elements of Job Enrichment and Organizational Performance among the Non Academic Staff in Nigerian Public Universities. Marketing and Management Journal, 12(2), 173-189. http://eprints.covenantuniversity.edu.ng/id/eprint/4227

Stritter, F. T., Bland, C. J., \& Youngblood, P. L. (1991). Determining Essential Faculty Competencies. Teaching and Learning in Medicine: An International Journal, 3(4), 232-238. https://doi.org/10.1080/10401339109539519

Teddlie, C., \& Tashakkori, A. (2009). Foundations of Mixed Methods Research: Integrating Quantitative and Qualitative Approaches in the Social and Behavioral Sciences: Sage Publication.

Velasco, P. J., Learreta, B., Kober, C., \& Tan, I. (2014). Faculty Perspective on Competency Development in Higher Education: An International Study. Higher Learning Research Communications, 4(4), 85-100.

Vijay, M. V., \& Indradevi, R. (2015). A Study on Job Enrichment and Individual Performance among Faculties with Special Reference to a Private University. Mediterranean Journal of Social Sciences, 6(1), 252-252. 